Accepted Manuscript

Title: ZINC(II) PHTHALOCYANINES AS

PHOTOSENSITIZERS FOR ANTITUMOR

PHOTODYNAMIC THERAPY

Authors: Leonor P. Roguin, Nicolás Chiarante, María C.

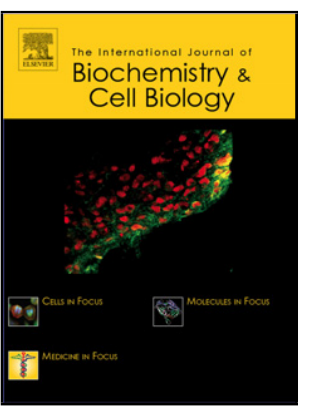

García Vior, Julieta Marino

PII:

S1357-2725(19)30152-9

DOI:

https://doi.org/10.1016/j.biocel.2019.105575

Article Number: 105575

Reference:

BC 105575

To appear in:

The International Journal of Biochemistry \& Cell Biology

Received date:

10 May 2019

Revised date:

18 July 2019

Accepted date:

22 July 2019

Please cite this article as: Roguin LP, Chiarante N, García Vior MC, Marino J, ZINC(II) PHTHALOCYANINES AS PHOTOSENSITIZERS FOR ANTITUMOR PHOTODYNAMIC THERAPY, International Journal of Biochemistry and Cell Biology (2019), https://doi.org/10.1016/j.biocel.2019.105575

This is a PDF file of an unedited manuscript that has been accepted for publication. As a service to our customers we are providing this early version of the manuscript. The manuscript will undergo copyediting, typesetting, and review of the resulting proof before it is published in its final form. Please note that during the production process errors may be discovered which could affect the content, and all legal disclaimers that apply to the journal pertain. 


\section{ZINC(II) PHTHALOCYANINES AS PHOTOSENSITIZERS FOR ANTITUMOR PHOTODYNAMIC THERAPY}

Running Title: Zinc(II) phthalocyanines as phototoxic agents

Leonor P. Roguin ${ }^{a^{*}}$, Nicolás Chiarante ${ }^{\mathrm{a}}$, María C. García Vior ${ }^{\mathrm{a}}$, Julieta Marino ${ }^{\mathrm{a}}$

anniversidad de Buenos Aires, Consejo Nacional de Investigaciones Científicas y

Técnicas, Instituto de Química y Fisicoquímica Biológicas (IQUIFIB), Facultad de Farmacia y Bioquímica, Junín 956, C1113AAD Buenos Aires, Argentina.

\section{To the memory of Prof. Dr. Josefina Awruch}

* Corresponding author: Leonor Patricia Roguin. Instituto de Química y Fisicoquímica Biológicas (UBA-CONICET), Facultad de Farmacia y Bioquímica, Junín 956, C1113AAD Buenos Aires, Argentina. Tel.: +54 114964 8290. E-mail: rvroguin@qb.ffyb.uba.ar

\section{Highlights}

- We present an updated summary on ZnPcs as antitumor photosensitizers

- ZnPcs localized in lysosomes, mitochondria or ER are efficient antitumor agents

- Apoptosis, necrosis and autophagy are the main cellular responses induced by $\mathrm{ZnPc}$ PDT

- Current efforts to improve in vivo PDT treatments with ZnPcs are discussed

- More clinical trials are required to evaluate $\mathrm{ZnPcs}$ as therapeutic agents

\section{Abstract}


Photodynamic therapy (PDT) is a highly specific and clinically approved method for cancer treatment in which a nontoxic drug known as photosensitizer (PS) is administered to a patient. After selective tumor irradiation, an almost complete eradication of the tumor can be reached as a consequence of reactive oxygen species (ROS) generation, which not only damage tumor cells, but also lead to tumor-associated vasculature occlusion and the induction of an immune response. Despite exhaustive investigation and encouraging results, zinc(II) phthalocyanines (ZnPcs) have not been approved as PSs for clinical use yet. This review presents an overview on the physicochemical properties of $\mathrm{ZnPcs}$ and biological results obtained both in vitro and in more complex models, such as 3D cell cultures, chicken chorioallantoic membranes and tumor-bearing mice. Cell death pathways induced after PDT treatment with ZnPcs are discussed in each case. Finally, combined therapeutic strategies including ZnPcs and the currently available clinical trials are mentioned.

Abbreviations: AIF, apoptosis-inducing factor; DCF-DA, 2',7'-dichlorfluorescein diacetate; EGFR, epidermal growth factor receptor; ER, endoplasmic reticulum; FAAD, Fas-associated death domian; GA, Golgi apparatus; LDH, Lactate dehydrogenase; NP, nanoparticles; PARP, poly(ADP-ribose) polymerase; PDT, photodynamic therapy; PEG, polyethylene glycol; PS, photosensitizer; Pcs, phthalocyanines; ROS, reactive oxygen species; UCNPs, upconverting nanoparticles; ZnPcs, zinc(II) phthalocyanines; ZnNcs, zinc(II)-naphthalocyanines.

Keywords: Photodynamic therapy; Zinc phthalocyanines; Photophysical properties; In vitro antitumor assays; In vivo tumor models 


\section{Introduction}

The first approaches to photodynamic therapy (PDT) are found in ancient texts such as the Egyptian medical treatise Ebers Papyrus and the Atharvaveda from the Hinduism. Despite this background, the observation of photochemical sensitization of tissues was first performed in detail by Raab (1900) in Germany and shortly afterwards by Von Tappeiner (1900), who coined the term "photodynamic action" to describe the treatment of skin tumors by using topical administration of eosin combined with sunlight (Kou et al., 2017). PDT is a therapeutic procedure based on the administration of a non-toxic photosensitizer (PS), which after activation by visible light in the presence of molecular oxygen, produces cytotoxic reactive oxygen species (ROS) that lead to cell damage (Henderson and Dougherty, 1992; Sharman et al., 1999; Detty et al., 2004; Plaetzer et al., 2009). Since the PS is preferentially localized into the cells to be treated and is activated only after irradiation of these cells, the PDT is a selective procedure frequently used for the treatment of a diversity of dermatological, ophthalmic and oncological diseases (Agostinis et al., 2011; van Straten et al., 2017). In clinical use, after topical or intravenous administration of a PS, the patient is irradiated with light of a suitable wavelength in the area to be treated and then maintained in the dark to minimize the probability of PS activation in other body regions. PS clearance 
from the organism will allow the patient to resume usual activities with exposure to both solar and artificial light.

At molecular level, light irradiation at a specific wavelength delivers the necessary energy to produce an electronic transition of the PS from its ground state to an excited singlet state of short half-life. The loss of energy caused by the return of electrons from the excited level to the basal energy level (deactivation process) may involve fluorescence/heat emission or intersystem crossing to generate a lower energy excited triplet state. Deactivation of this triplet species can occur mainly by two mechanisms, known as type I or type II reactions, that generate reactive oxygen species (ROS) (Agostinis et al., 2011; Oliveira et al., 2011; Gomes et al., 2018). In type I reactions, the PS transfers an electron to biological substrates to form free radicals, which finally give rise to cytotoxic species such as superoxide anion, hydrogen peroxide and hydroxyl radicals. In type II reactions, the triplet oxygen $\left({ }^{3} \mathrm{O}_{2}\right)$ is converted into singlet oxygen $\left({ }^{1} \mathrm{O}_{2}\right)$, a highly cytotoxic species with a very short half-life, between 10 and $320 \mathrm{~ns}$ (Agostinis et al., 2011). As this species can diffuse 10-55 nm on average, a distance that represents one thousandth of the diameter of eukaryotic cells, the intracellular organelles containing the PS are considered to be the main sites where the phototoxic damage is triggered. The final consequence of the ROS formation is the induction of a cell death process, the destruction of the microvasculature and the activation of a local inflammatory reaction that may trigger an immune response (Engbreht et al., 1999; Castano et al., 2006; Buytaert et al, 2007; van Straten et al., 2017).

Many photo-activable molecules, including porphyrins, phthalocyanines, chlorines and bacteriochlorine derivatives, among others, have been found to be useful candidates for PDT applications (Gomes et al., 2018; Kou et al., 2017). In the 70's, the use of PDT as a therapeutic option generated a renewed interest in the oncological field from the performance of systematized trials for tumors treatment (Diamond et al., 1972). Dougherty et al. (1975, 
1978) carried out the first clinical trial in patients with Photofrin ${ }^{\circledR}$ as photosensitizer. This PS together with other porphyrin derivatives formed the first generation of PSs. This group of PSs showed some unfavourable characteristics, including low absorptions in the red light region (range between 600 to $800 \mathrm{~nm}$, where tissue light penetration is high), poor solubility in polar solvents and skin phototoxicity (Allison and Sibata, 2010; Kou et al., 2017; Gomes et al., 2018). Due to this last feature, the patient has to take extreme precautions from environmental light exposure. The second generation of PSs emerged either from structural modifications made on the macrocycles of the first generation or from changes in the synthetic routes to generate new families of molecules. These new compounds, more similar to what is expected for an ideal PS, include chlorine or bacteriochlorin, benzoporphyrin (or new porphyrin derivatives), purpurins, texaphyrins and phthalocyanines (Kou et al., 2017; Gomes et al., 2018). Among these PSs, the phthalocyanines (Pcs) have drawn attention as promising antitumor phototoxic drugs. Besides various physicochemical characteristics that will be mentioned later, several Pcs coordinated to zinc, aluminum or silicon are very efficient generators of singlet oxygen (Paquette et al., 1991; Boyle et al., 1992; Margaron et al., 1996; Colussi et al., 1999). Afterwards, the third generation of PSs was developed to promote a higher and more specific accumulation of PS in target cells. The main strategies employed to achieve this objective involve PS binding to antibodies (Kudarha and Sawant, 2017; Pereira et al., 2014a) or incorporation to nanocarriers (Abrahamse et al., 2017; Yang et al., 2017).

In this review, among the extensive list of recognized PSs for cancer treatment, we focus on the characteristics of zinc(II) phthalocyanines (ZnPcs), as many variants of this type of photo-activable drugs with improved physicochemical and biological properties have been developed in the last years (Figure 1). The photophysical properties of ZnPcs, the in vitro 
antitumor mechanism of action in $2 \mathrm{D}$ and $3 \mathrm{D}$ cell cultures, and the in vivo effectiveness as anticancer agents in animal models and clinical trials will be herein summarized.

\section{Physicochemical properties of zinc(II) phthalocyanines}

\subsection{Zinc(II) phthalocyanines for PDT}

Phthalocyanines are synthetic dyes that were first obtained by Braun and Tcherniac in 1907. Pcs are aromatic heterocycles that consist of four units of isoindoles bridged by nitrogen atoms. They have a characteristic UV-visible absorption spectrum with two main bands: the weak Soret band located in the UV zone of the spectrum at $\sim 350 \mathrm{~nm}$ and the Q band, located in the red zone of the visible spectrum at around $680 \mathrm{~nm}$, whose high intensity is one of the main characteristics of these dyes with a molar extinction coefficient of $1 \times 10^{5}$ $\mathrm{M}^{-1} \mathrm{~cm}^{-1}$, two orders of magnitude higher than most porphyrins (Leznoff and Lever, 1989). Their photochemical properties are strongly influenced by the nature of the coordinated central metal ion. Thus, the presence of diamagnetic elements in the central cavity, such as zinc (II), aluminum (III), gallium (III) or silicon, gives them high triplet quantum yields ( $\left.\Phi_{\mathrm{T}}>0.4\right)$ with long triplet lifetimes $\left(\tau_{\mathrm{T}}>100 \mu \mathrm{s}\right)$ and adequate triplet energies $\left(\mathrm{E}_{\mathrm{T} 1}=1.2 \mathrm{eV}\right)$, making them efficient generators of singlet oxygen $\left(\Phi_{\Delta}>0.4\right)$ (Lagorio et al., 1993).

ZnPcs have advantageous characteristics including low dark toxicity, high chemical and photochemical stability, high therapeutic effect, minimal skin photosensitivity and excitation at wavelengths greater than $630 \mathrm{~nm}$, which allows greater tissue penetration of radiation (Jori, 1992; Marino et al., 2010). Despite these attractive features, one disadvantage of Pcs is their poor solubility in organic solvents (Nyokong and Antunes, 2010). Their solubility can be increased by introducing peripheral ( $\beta$ position) and non-peripheral ( $\alpha$ position) substituents in the Pc framework (Figure 1). The tetrasubstituted Pcs are usually more soluble than octasubstituted due to the formation of constitutional isomers and the high 
dipole moment resulting from the asymmetric rearrangement of the substituents (Leznoff et al., 1985). However, the four possible structural isomers of a tetrasubstituted Pc are difficult to separate and purify (Hanack et al., 1993).

On the other hand, the formation of aggregates in solution decreases the capacity to produce singlet oxygen because the photochemical activity is exclusively related to monomer species. Thus, aggregates decrease not only the photoactivity of the PS but also limit the access to the neoplastic cells, affecting its bioavailability. The presence of bulky or electrically charged peripheral substituents bound to the macrocycle and/or axial ligands coordinated to the central metal minimizes the tendency to form aggregates (García Vior et al., 2009, Wang et al., 2012; Muli et al., 2015). Ke et al. (2009) demonstrated that tetra- $\alpha-$ substituted $\mathrm{ZnPcs}$ exhibit a reduced aggregating trend, higher photostability and enhanced photocytotoxicity toward human gastric carcinoma cells than the tetra- $\beta$-substituted counterparts. Our group also showed a similar behavior when the photodynamic effect of $\alpha$ and $\beta$ cationic substitution of $\mathrm{ZnPcs}$ was studied in human nasopharynx KB carcinoma cells (Marino et al., 2010).

In order to improve water solubilization of $\mathrm{ZnPcs}$, the synthesis of anionic derivatives containing sulfonic (Haywood-Small et al., 2006; Lan et al., 2016), phosphonic (Venkatramaiah et al., 2015) or carboxylic groups (Zhou et al., 2016) has been carried out. For instance, Zhou et al. (2016) demonstrated that a ZnPc substituted with $16 \mathrm{COOH}$ groups existed in its monomeric form under physiological conditions and showed superior ${ }^{1} \mathrm{O}_{2}$ generation than other derivatives containing less $\mathrm{COOH}$ groups. To control the degree of aggregation in aqueous media, Ikeuchi et al. (2016) synthetized a water-soluble ZnPc bearing four 3-sulfone-linked propylsulfonyl at non-peripheral positions. Other authors have also demonstrated the importance of positive charges in ZnPcs (Wood et al. 1997, Li et al., 2008; Sekhejane et al., 2014; Wang A. et al. 2014). In this sense, we studied the synthesis and 
photophysical properties of cationic bioisosteric ZnPcs containing peripheral chains bound to the macrocycle by oxygen, sulfur or selenium (García Vior et al., 2009; Marino et al. 2010; Gauna et al., 2011, Ezquerra Riega et al., 2018). A bathochromic shift of 8-10 nm for the Qbands of $\mathrm{ZnPcs}$ was observed when sulfur or selenium were present, allowing the excitation of PSs in deeper regions of a tissue. In addition, although selenium ZnPcs reported the highest value of quantum yield of $\Phi_{\Delta}$, both selenium and sulfur substituted ZnPcs showed similar phototoxic activities in colon carcinoma cells (Ezquerra Riega et al., 2018).

\subsection{Third generation zinc(II) phthalocyanines}

Even though lipophilic PSs show an increased tumor to normal tissue ratio (Stockert et al., 2004), the intravenous administration is difficult. To overcome this issue and avoid post-PDT skin photosensitivity, the so-called third generation PSs have been developed. They comprise second generation PSs associated to a carrier able to promote PS accumulation in tumor cells, to reduce aggregation tendency and minimize localization in normal cells. On these bases, formulation of $\mathrm{ZnPcs}$ in different nanosized delivery systems has been attempted. In the last years the most studied carriers include liposomes (de Oliveira et al., 2010; Garcia et al., 2011; López Zeballos et al., 2013; Kim et al., 2014), polymeric micelles (García Vior et al., 2013; Pucelik et al., 2016; Lamch et al., 2016; Debele et al., 2017) and different types of nanoparticles (NPs) (Camerin et al., 2010; Ping et al., 2016; Oluwole et al., 2016; Yurt et al, 2017), all of which showed an increase in the bioavailability, stability and transport of $\mathrm{ZnPcs}$ to the target tissue. Our group, after studying the incorporation of a lipophilic tetrasubstituted $\mathrm{ZnPc}$ into polymeric micelles and different liposomes, demonstrated a similar increase in solubility for both carriers, but a higher photodynamic activity against tumor cells in micellar formulations (López Zeballos et al., 2013; García Vior et al., 2013; Chiarante et al., 2017). ZnPc molecules have been also encapsulated into NPs of different nature, such as polymeric NPs (Conte et al., 2013; Ping et 
al., 2016; Huang et al., 2016), $\mathrm{TiO}_{2}$ NPs (Yurt et al, 2017; Lopez et al., 2010), gold NPs (Camerin et al., 2010; Manoto et al., 2017a; Mfouo-Tynga et al., 2018a, 2018b; Dube et al., 2018; Garcia Vior et al., 2019) and silica based NPs (Tu et al., 2012; Oluwole et al., 2016). Ricci-Junior et al. (2018), after evaluating the photobiological activity of three nanosystems (nanoparticles, nanoemulsions and mesoporous silica) containing $\mathrm{ZnPc}$, demonstrated that all of these formulations could be used for clinical purposes in PDT. Furthermore, upconverting nanoparticles (UCNPs), based on the absorption and conversion of near infrared light to visible photons that can further activate the PS, have been efficiently employed as PDT carriers for ZnPcs (Guo et al., 2010; Tian et al., 2013; Wang H. et al., 2014a; Hou et al., 2015).

Targeting moieties that recognize specific sites expressed in tumor cells have been coupled to nanocarriers to improve $\mathrm{ZnPcs}$ accumulation. For instance, $\mathrm{ZnPcs}$ surrounded by a carbohydrate shell of galactose (Pereira et al., 2014b) or lactose (García Calavia et al., 2018) units have shown to increase tumor selectivity, since cancer cells are known to overexpress carbohydrate-binding proteins, such as galectin-1 and the glucose GLUT-1 transporter. Folic acid incorporated into micelles (Liang et al., 2014a) or UCNPs (Cui et al., 2013) has been employed for targeting cancer cells overexpressing folate receptor. Wang $\mathrm{H}$. et al. (2014b) demonstrated the efficacy of ZnPc and UCNP encapsulated into lipid micelles carrying cell-penetrating peptides. Likewise, ZnPcs conjugated with peptides or antibodies directed to EGFR have been properly incorporated by cells overexpressing EGFR (Ongarora et al., 2012a; Broekgaarden et al., 2016a). UCNPs conjugated with ZnPc and the monoclonal antibody Trastuzumab were designed by Ramirez Garcia et al. (2018) for specific HER2positive breast cancer detection and PDT.

\section{In vitro photodynamic assays of zinc(II) phthalocyanines}




\subsection{ROS formation, cellular uptake and intracellular localization}

As already mentioned, an appropriate PS should be capable of inducing an efficient formation of ROS after being irradiated. Among these phototoxic species, the main reacting species in vivo seems to be singlet oxygen (Agostinis et al, 2011; Gomes et al., 2018). Although this species has short life-time and short radius of action, cell damage is initiated in the intracellular sites where the PS is localized. Consequently, the oxidative damage begins the cascade of molecular events that finally lead to cell death (Oleinick et al., 2002; Chiu et al., 2010; Kessel, 2004). Based on the complexity imposed by cellular models, the ability of PSs to generate ROS has to be tested not only in fluid media but also in cellular environments. To this end, intracellular ROS content can be measured by using a fluorescent probe, such as $2^{\prime}, 7^{\prime}$-dichlorfluorescein-diacetate (DCFH-DA). This probe, after diffusing into cells, is deacetylated by esterases and then oxidized to the fluorescent $2^{\prime}, 7^{\prime}$ dichlorfluorescein (DCF) in the presence of ROS (mainly hydrogen peroxide and lipid hydroperoxides). DCF fluorescence is in general detected by fluorescence microscopy, flow cytometry or with a fluorometer. All the ZnPc-based photosensitizers studied so far in cell cultures showed high ROS generation quantum yields, revealing that they behave as competent PSs for PDT applications (Yu W et al., 2018; Nag et al., 2018; Wang et al., 2017; Lu et al., 2016). In spite of this property, it should be taken into account that tumor hypoxia might reduce the antitumor efficacy of PDT due to the activation of the hypoxia-inducible factor $1 \alpha(\mathrm{HIF}-1 \alpha)$. In this regard, it was demonstrated that combined treatments of $\mathrm{ZnPc}$ with a HIF-1 $\alpha$ inhibitor improved PDT efficacy in human carcinoma cells (Weijer et al., 2016; Broekgaarden et al., 2016b).

The intracellular PS location, which determines both the primary site of photodamage and the mechanisms of cell death, is markedly influenced by the structural characteristics of the PS and the type of cell. In addition, cellular uptake of ZnPcs is a time- and concentration- 
dependent process. These fluorescent dyes are distributed homogeneously in the cytosol, as shown by confocal microscopy studies, and no evidence of nuclear localization has been detected. The mechanism of ZnPcs internalization seems to be dependent on the vehicule used to dissolve the PS. In this sense, Soriano et al. (2013) demonstrated that caveolinmediated endocytosis was responsible for internalizing a $\mathrm{ZnPc}$ dissolved in dimethylformamide, while an endocytic pathway dependent on clathrin mediated the incorporation of $\mathrm{ZnPc}$ included in liposomes.

By using organelle-specific fluorescent probes, $\mathrm{ZnPcs}$ have been mainly found in mitochondria, lysosomes, endoplasmic reticulum (ER), plasma membrane or Golgi apparatus (GA) (Figure 2). Despite the variety of studies on the main sites of intracellular accumulation of $\mathrm{ZnPcs}$, it is still not very simple to establish a clear relationship between the subcellular localization and the structural characteristics of these PSs. For instance, by working with an unsubstituted ZnPc, Fabris et al. (2001) showed that a liposomal formulation of the PS mainly localized in GA and plasma membrane after $2 \mathrm{~h}$ of incubation with transformed fibroblast, whereas both GA and mitochondrial localization were found after 24 h of exposure. Soriano et al. (2014), using a liposomal formulation of the same PS in HeLa cells, reported a similar intracellular localization after short incubation periods. Although these results suggested that the incubation time is a variable that must be considered in subcellular localization studies, Cristobal et al. (2006) found that a ZnPc/liposomal formulation localized in GA, but not lysosomes or mitochondria, after either 3 or $18 \mathrm{~h}$ of incubation with lung carcinoma cells.

The localization of a $\mathrm{ZnPc}$ dissolved in dimethylformamide or incorporated into a network of titanium dioxide was studied by Lopez et al. (2010) after $24 \mathrm{~h}$ of incubation in different cell lines. These authors reported an exclusive mitochondrial or lysosomal localization of the PS tested depending on the cell line studied. In 2013, Shao et al., with the 
aid of specific organelle-probes, concluded that the unsubstituted $\mathrm{ZnPc}$ solubilized in the Cremophor EL formulation mainly localized in mitochondria, lysosome and ER after $24 \mathrm{~h}$ of incubation with hepatocellular carcinoma cells. Based on the dissimilar findings found with different formulations of unsubstituted $\mathrm{ZnPc}$, it is possible to conclude that either the intrinsic properties of each formulation, the type of cell, the incubation time or the fluorescent probes employed to detect subcellular organelles could influence the results obtained.

Regarding studies performed with substituted ZnPcs, Wood et al. (1997) showed that while anionic and cationic polysubstituted $\mathrm{ZnPcs}$ localized in lysosomes, neutral ZnPcs accumulated in GA. Afterwards, a great number of reports showed that either mono or polysubstituted ZnPcs target mainly to mitochondria and/or lysosomes, and in a lower degree to ER. In this regard, the mitochondrial and lysosomal localization of mixed sulfonated $\mathrm{ZnPc}$ (ZnPcSmix) has been shown in different cell types (Manoto et al, 2012; Manoto el al, 2013; Mfouo-Tynga et al., 2013; Sekhejane et al, 2014). The same distribution pattern was observed by Li et al. (2012) working with ZnPc-(Lys)n, a group of amphipathic monosubstituted $\mathrm{ZnPcs}$ conjugated to different numbers of lysine residue. Therefore, both mitochondrial and lysosomal localization have been reported for either negatively or positively charged PSs. Similarly, independently of the charge or the hydrophobic/hydrophilic nature of the PS, just a lysosomal accumulation was reported for hydrophobic ZnPcs, such as sulfur-linked octaalkylamino substituted ZnPc (Rumie Vittar et al., 2008), methoxy (Yslas et al., 2007) or amine-terminated monosubstituted ZnPcs (Peng et al., 2017), and hydrophilic ZnPcs, as cationic sulfur-linked (Gauna et al., 2011) or arginine substituted ZnPcs (Wang et al., 2017).

A series of cationic $\mathrm{ZnPcs}$ conjugated to a bifunctional peptide were only found in lysosomes (Sibrian-Vazquez et al., 2007). On the other hand, Ge et al. (2013) reported the design and synthesis of an specific mitochondria-targeted ZnPc substituted with a quaternary 
ammonium salt on the periphery, whereas Muli et al. (2008), based on the properties of rhodamine $\mathrm{B}$ to target mitochondria, described the synthesis and characterization of asymmetric ZnPc-rhodamine B conjugates for selective mitochondrial targeting. Duan et al. (2010) also showed a selective affinity to the mitochondria of a non-ionic 2(dimethylamino)ethylthio ZnPc. In addition, the effect of the formulation on the intracellular localization of ZnPcs should not be neglected. In this sense, Lan et al. (2016) described a restricted mitochondrial localization or a mitochondrial/lysosomal localization for a $\mathrm{ZnPc}$ substituted with sulfonated quinolineoxy groups and formulated either with Cremophor EL or PBS. It should also be considered that the exclusive mitochondrial localization of ZnPcbased PSs found in several reports responds to the employment of just a specific mitochondrial probe (Oluwole et al., 2017; Ke et al., 2017; Huang et al., 2016; Lo et al., 2007; Alexandratou et al., 2005).

Our group demonstrated a lysosomal localization of a water-soluble tetrasubstituted $\mathrm{ZnPc}$ replaced with sulfur-linked cationic aliphatic chains in the human nasopharynx $\mathrm{KB}$ carcinoma cell line (Marino et al., 2010). The same cationic phthalocyanine targeted lysosomes and mitochondria in murine melanoma cells (Valli et al., 2019), reinforcing the concept that the intracellular location may vary according to the cell line studied. We also reported a preferential lysosomal localization of a lipophilic ZnPc (Pc9: tetrakis-[(2dimethylamino)ethylsulfanyl]phthalocyaninatozinc(II)) loaded either into liposomes or poloxamine micelles in KB cells (García Vior et al., 2013; López Zeballos et al., 2013). Since both formulations showed different phototoxic potencies ( $\mathrm{IC}_{50}$ values were in the range of 0.21-0.47 $\mu \mathrm{M}$ for Pc9-loaded into liposome formulations and 9.5-22 $\mathrm{nM}$ for Pc9-micelles formulations), the results herein obtained suggested that PS location was independent of the vehicle used and other factors, such as a differential uptake, could explain the variation in potency. At comparable intracellular concentrations, Garcia et al. (2016) demonstrated that 
the intracellular fate of the PS did depend on the nature of the vehicle used. In this case, when the location of an unsubstituted $\mathrm{ZnPc}$ internalized in liposomes or BSA was studied, ZnPc:BSA preferentially located in GA, while the liposomal formulation was mostly located in the cellular membrane. In the last years, as interest in the role of ER in phototoxic cell death increased, various studies focused on this organelle as possible localization site. However, it must be taken into account that while lysosomal and mitochondrial probes have been extensively used for the study of $\mathrm{ZnPcs}$, ER probes have been employed to a lesser degree. As mentioned before, Shao et al. (2013) verified the ER location of a $\mathrm{ZnPc} / \mathrm{Cremophor} \mathrm{formulation} \mathrm{by} \mathrm{using} \mathrm{an} \mathrm{ER} \mathrm{fluorescent} \mathrm{Tracker.} \mathrm{Likewise,} \mathrm{when} \mathrm{Manoto}$ et al. (2012) demonstrated the mitochondrial and lysosomal distribution of ZnPcSmix in different tumor cell types, they also verified the absence of co-localization in the ER with a specific probe. Ongarora et al. (2012b), after studying the subcellular distribution of a series of cationic ZnPcs in tumor cells, showed that although these compounds localized in multiple sites within the cell (such as mitochondria, lysosomes, ER and GA), the most active ones containing a PEG group- were mainly found within the ER, suggesting that pegylation could favor the intracellular localization in the ER. Fujishiro et al. (2018) also reported that a cationic ZnPc carrying N-methyl-pyridinium groups was observed in greater amounts in the ER, Golgi, and lysosomes, whereas Kiew et al. (2017), working with a ZnPc conjugated to poly-L-glutamic acid, revealed a high co-localization in lysosomes and partial colocalization with the ER and mitochondria. In our laboratory, we explored the intracellular distribution of a micellar formulation of a lipophilic ZnPc in CT26 colon cells, and found preferential photosensitizer incorporation into lysosomal vesicles and ER cisterns, but not mitochondria (Chiarante et al., 2017).

In summary, since the subcellular localization of PSs is directly related to the mechanisms involved in cell oxidative damage, we strongly believe that a rigorous study of 
the subcellular localization of $\mathrm{ZnPcs}$, using a complete battery of organelle-specific probes, is an important step to achieve a clear understanding of the type of cell death.

\subsection{Mechanisms of cell death}

The photo-oxidative damage caused by PDT in tumor cells may activate different modalities of cell death, which can act independently, simultaneously or in combination, depending on the nature of PS, the administered dose, the cell type and the light exposure dose. Accordingly, for each tumor cell line treated under specific experimental conditions with a particular type of PS, the intracellular localization of the PS strongly determines the mode of cell death. The most frequent cellular responses induced in 2D or 3D cultures after PDT treatment include apoptosis, necrosis and autophagy (Butyaert et al., 2007; Agostinis et al., 2011; Mroz et al., 2010) (Figure 2). More recently, but only in 2D cultures, paraptosis has been described as a type of cell death induced by PSs that target the ER for photodamage, but it has not been described yet for ZnPcs (Kessel, 2018; Kessel and Oleinck, 2018; Kessel, 2019). Apoptosis has been recognized as a frequent mechanism associated to the photooxidative damage induced by PDT (Buytaert et al., 2007) and has been extensively characterized after ZnPc-induced photodamage. This cell death programme is mediated through the activation of either death receptor or mitochondrial-dependent pathways (extrinsic and intrinsic pathways, respectively), usually regulated by caspases (Grütter, 2000; Kaufmann and Hengartner, 2001; Galluzzi et al., 2012).

3.2.1. Death receptor-dependent apoptosis: although the extrinsic pathway of apoptosis can contribute to the PDT-induced apoptotic response (Butyaert et al., 2007), few evidence of the involvement of this pathway after photodamage triggered by ZnPcs are found. The activation of the receptor death machinery has been suggested by Machado et al. (2009) who showed that Fas dimerization induced by p38MAPK activation in tumor cells treated with a $\mathrm{ZnPc}$ favors the formation of the Fas-FADD death complex needed to activate caspase 8 . On 
the other hand, the decrease of Fas levels reported by Xia et al. (2011), after PDT treatment with a tetra- $\alpha$-(4-carboxyphenoxy) ZnPc, suggested indeed an alteration of the death receptor complex assembly. Therefore, it seems that more than a direct involvement of this pathway, some molecular signals induced after ZnPcs PDT could be responsible for the activation or inhibition of an extrinsic apoptotic response.

3.2.2. Mitochondrial-dependent apoptosis: since mitochondrial homeostasis is essential for cell viability, the damage to this organelle after ZnPcs PDT has been extensively studied taking into account both the mitochondrial localization of PSs and a possible downstream effect due to the injury initiated at other subcellular locations. Caspases activation, deregulation in the expression levels of Bcl-2 family proteins, reduction of mitochondrial membrane potential, cytosolic release of cytochrome c, PARP cleavage and chromatin condensation, among others, have been characteristics widely explored following ZnPcs PDT (Figure 3). Thus, after treatment, activation of caspases 8 and 9, leading to the cleavage of procaspase 3, has been reported in different cell types (Shao et al., 2013; Wang Y et al., 2014; Doustvandi et al., 2017; Wang Y et al., 2018a). A time- and dose-dependent increase of the executioner caspase 3 has been described after irradiation of both unsubstituted and substituted ZnPcs (Fabris et al., 2006; Shao et al., 2012; Kuzyniak et al., 2017). Interestingly, an apoptotic caspase-independent mechanism has been described after irradiation of a watersoluble octakis(3-aminopropyloxy) ZnPc in a human breast adenocarcinoma cell line (Rumie Vittar et al., 2010). In this work, the authors showed that ZnPc PDT induces the translocation of the apoptosis-inducing factor (AIF) to the nucleus, a mediator involved in DNA fragmentation in a caspase-independent manner (Figure 3). Also noteworthy, Doustvandi et al. (2017), after exploring the apoptotic response induced by a ZnPc at different light doses, suggested that an increase in light dose could switch a caspase-independent apoptotic mechanism to a caspase-dependent one. 
Regarding the involvement of other caspases, some insights have been reported about the role of caspase 2 after PDT with ZnPcs. Thus, Cristóbal et al. (2006) demonstrated that caspase 2 was rapidly activated after treatment with a ZnPc liposomal formulation exclusively located in GA and suggested that this activation preceded the disorganization of the organelle to trigger an apoptotic response. Later, Mfouo-Tynga et al. (2014), by using ZnPcSmix, showed that the proteolytic caspase 2 cleaves and activates Bid into its truncated form (tBid) to promote mitochondrial permeabilization. Other studies with substituted $\mathrm{ZnPcs}$ also demonstrated that Bid cleavage occurs after irradiation (Rumie Vittar el al., 2010; Marino et al, 2013; Chiarante et al., 2018), although, in most reports, caspase 8 and lysosomal proteases have been identified as the main enzymes responsible for Bid fragmentation (Butyaert el al, 2007; Kessel and Oleinick, 2018) (Figure 4).

The unbalance in the expression levels of Bcl-2 family proteins unquestionably plays a role in the mitochondria-mediated cell death (Figure 3). A down-regulation of antiapoptotic Bcl-2 proteins (Machado et al., 2009; Dai et al., 2016; Doustvandi et al., 2017; Zamani et al., 2018) and up-regulation of some apoptotic proteins, such as Bak (Liu et al., 2017) and Bax (Machado et al., 2009; Dai et al., 2016; Zamani et al., 2018), have been commonly informed after PDT treatment with different formulations of $\mathrm{ZnPcs}$ in a wide variety of cell types. In some cases, although Bax levels remained unchanged after irradiation (Marino et al., 2013; Kuzyniak et al., 2016), a clear translocation of this protein from cytosol to mitochondrial membrane suggested its involvement in the opening of mitochondrial pores (Rello-Varona et al., 2008; Acedo et al., 2014). As a consequence of changes in Bcl-2 proteins, ZnPcs PDT treatment leads to the loss of mitochondrial membrane potential regardless of the chemical nature of the PS employed (Alexandratou et al., 2005; Huang et al., 2005; Shao et al., 2013; Ge et al., 2013) and the release of apoptogenic molecules, such as cytochrome c, to the cytosol (Medina et al., 2009; Marino et al., 2013; Soriano et al., 2014). The cytosolic release 
and nuclear translocation of other mitochondrial apoptogenic species, such as AIF, have also been demonstrated after irradiation of some substituted ZnPcs (Rumie Vittar et al., 2010; Wang Y et al., 2018a).

3.2.3. Lysosomal membrane permeabilization: PSs mainly located in lysosomes are expected to permeabilize lysosomal membrane upon light activation and promote mitochondrial injury through the release of lysosomal proteases into the cytosol (Figure 4). The contribution of lysosomal enzymes to the apoptotic response following photodamage has been earlier described (Reiners et al., 2002; Cirman et al., 2004; Ichinose et al., 2006). In particular, the first reports of $\mathrm{ZnPcs}$ affecting lysosomal integrity involved fluorescence microscopy studies. These works showed either a loss of the fluorescent punctuate staining of the specific LysoTracker Green probe after irradiation of different tumor cells (Yslas et al., 2007; Rumie Vittar et al., 2008; Manoto et al., 2013) or the lost of the acridine orange probe from intact acidic lysosomes (Marino et al., 2013; Sun et al., 2017; Chiarante et al., 2018). Studies performed in our laboratory either with a cationic (Marino et al., 2013) or a lipophilic (Chiarante et al., 2018) ZnPc located in lysosomes revealed that PDT treatment promotes the cytosolic release of the lysosomal protease cathepsin D in a ROS-dependent manner, since the expression levels of cathepsin D significantly diminished in the presence of antioxidants. We further showed that Bid cleavage was inhibited in the presence of a Pepstatin A, a cathepsin D inhibitor, supporting a role of cathepsin D in Bid activation (Marino el al., 2013). In addition, the reduction of caspase 8 activity observed after incubation of ZnPc-treated with Pepstatin A supported the involvement of cathepsin D in caspase 8 activation (Chiarante et al., 2018) (Figure 4).

3.2.4. ER stress: as a key organelle involved both in the folding and trafficking of newly synthesized proteins as well as in the maintenance of $\mathrm{Ca}^{2+}$ homeostasis, ER photodamage after PDT can contribute to an apoptotic cell death (Buytaert et al., 2007; Moserova and 
Kralova, 2012). In the field of ZnPcs, Yu L et al. (2018) reported the ER localization of a biotinylated glutathione-responsive ZnPc that triggers ER stress after light irradiation. Studies performed in our laboratory with a lipophilic ZnPc also showed that ER stress induced by PDT can be propagated to the mitochondrial apoptotic pathway (Chiarante et al., 2018). In both reports, an increase of intracellular $\mathrm{Ca}^{2+}$ concentration and higher expression levels of ER stress marker proteins, such as BIP/GRP78 and CHOP/GADD153, were demonstrated after photoactivation (Figure 5). Remarkably, we also demonstrated that calpains, activated by the high cytosolic $\mathrm{Ca}^{2+}$ concentrations reached after ER stress, contribute to Bax proteolytic damage (Chiarante et al., 2018). This Bax fragmentation, as it was shown in other apoptotic processes, could favor the formation of a more apoptotic fragment (Toyota et al., 2003).

3.2.5. Necrosis: the first works addressing the mechanism of tumor necrosis showed areas of necrotic degeneration in tumor tissues treated by PDT with unsubstituted ZnPcs (Milanesi et al., 1990; van Leengoed et al., 1994; Ruck et al., 1996; Winsborrow et al., 1997). Necrotic regions were also described following in vivo PDT treatment with more complex formulations of ZnPcs (Allémann et al., 1997; Hu et al., 1998; Porthilo et al., 2013). Since tumor necrosis was defined by the analysis of histological tumor sections or the macroscopic appearance of PDT-treated tumors, it should be taken into account that these necrotic areas do not actually reflect the mechanism of cell death. Indeed, in cell cultures, necrosis is characterized by several features, including extensive plasma membrane damage, cell swelling, release of cellular contents to the environment, swelling of cytoplasmic organelles and moderate chromatin condensation (Galluzzi et al., 2007). In the field of PDT, although several of the typical characteristics of necrosis were identified in tumor cell lines after treatment with $\mathrm{ZnPc}$ formulations, sometimes the necrotic process might be secondary to a late apoptosis (de Oliveira et al., 2010; Broekgaarden et al., 2015). In addition, it is generally 
considered that the necrotic cell death induced by photodamage predominates at high doses of PDT (Oleinick et al., 2002). In this regard, Yslas et al. (2007), by working with a $0.5 \mu \mathrm{M}$ concentration of a substituted $\mathrm{ZnPc}$, showed that PDT treatment can induce either necrosis or an apoptotic cell death depending on the light dose used. Thus, while an apoptotic pathway occurs mainly at a light dose of $11 \mathrm{~J} / \mathrm{cm}^{2}$, necrosis predominates at $29 \mathrm{~J} / \mathrm{cm}^{2}$. Similarly, Acedo et al. (2014) demonstrated that the simultaneous administration of a $\mathrm{ZnPc}$ and a cationic porphyrin changes the mechanism of cell death from apoptosis to necrosis when the light dose increases from 2.4 to $3.6 \mathrm{~J} / \mathrm{cm}^{2}$. Interestingly, our group reported a dual apoptotic and necrotic response triggered by a sulfur-linked cationic $\mathrm{ZnPc}$ located both in lysosomes and mitochondria in melanoma cells. In this case, although necrosis increased at high light doses or PS concentrations, this type of cell death was also detected simultaneously with the activation of an apoptotic response after irradiating cells with $340 \mathrm{~mJ} / \mathrm{cm}^{2}$ (Valli et al., 2019).

Fabris et al. (2001) showed that necrosis represents the main mode of death of transformed fibroblasts incubated with a liposomal formulation of an unsubstituted $\mathrm{ZnPc}$ mainly localized in the GA and plasma membrane after short periods of incubation, whereas after $24 \mathrm{~h}$ of exposure, morphological changes typical of apoptosis were observed when the Pc was found in GA and also in mitochondria. Soriano et al. (2014) reported a necrotic cell death induced after PDT with a ZnPc located in the plasma membrane, but the induction of a process of regulated necrosis (necroptosis) when the PS is located in the GA. Kim et al. (2014) developed a liposomal delivery system to localize an hydrophobic ZnPc selectively into the plasma membrane and showed that a substantial membrane disruption occurs upon irradiation, leading to a necrosis-like cell death. Thus, in a broad sense, the occurrence of PDT-induced apoptosis or necrosis may depend on several factors, including the PS used and its intracellular localization, the light dose, incubation times, the cell type and even the nature of the formulation. About the influence of the vehicle, de Oliveira et al. (2010), after 
evaluating the phototoxic activity of different $\mathrm{ZnPcs}$ liposomal formulations containing cholesterol, showed that the phototoxicity is totally dependent on the presence of cholesterol and cell death of irradiated tumor cells is consistent with necrosis. Later, García et al. (2016) revealed different mechanisms of cell death for $\mathrm{ZnPcs}$, depending both on the delivery vehicle and the PS intracellular location, being apoptosis dominant for ZnPcs formulations preferentially accumulated in GA, and necrosis for those located in cell membrane.

3.2.6. Autophagy: this process displays a dual role, since it may induce either a survival response or contribute to a death pathway (Butyaert et al., 2007; Kessel and Oleinik, 2018). In the field of ZnPcs, Yu et al. (2019) demonstrated that PDT treatment with an unsubstituted ZnPc and the autophagy inhibitor 3-methyladenine inhibited tumor growth in a model of tumor metastasis, indicating that autophagy indeed exerts a protective role. On the other hand, Mfouo-Tynga et al. (2018b), after PDT treatment of breast cancer cells with a novel formulation of $\mathrm{ZnPcSmix}$ and gold nanoparticle encapsulated dendrimers, showed an upregulation of ULK-1, an autophagy gene that has been reported to contribute to cellular damage and death.

\section{Photodynamic effect of $\mathrm{ZnPcs}$ in 3D cultures and in vivo assays}

In order to evaluate the contribution of the cellular environment, tumor vasculature and the immunological response in PDT efficacy, more complex tumor models, that resemble more closely what actually happens in the treatment of oncological diseases, are required. To this end, 3D spheroids, chicken chorioallantoic membrane and animal tumor assays have been employed to examine the antitumor efficacy of $\mathrm{ZnPcs}$.

\subsection{Multicellular tumor spheroids (MCTS)}


These 3D cell aggregates represent models intermediate in complexity between 2D cultures and in vivo tumors (Sutherland et al., 1970). A few works employing MCTS showed that photoactivation of $\mathrm{ZnPcs}$ could efficiently reduce cell viability. Studies performed in our laboratory with a micellar formulation of a lipophilic $\mathrm{ZnPc}$ revealed that although an efficient phototoxic response was observed after treatment of colon tumor spheroids, almost a 40 times higher $\mathrm{IC}_{50}$ value was obtained in $3 \mathrm{D}$ cultures with respect to $2 \mathrm{D}$ cell monolayers (Chiarante et al., 2017). Similar differences in the phototoxic response were observed by Manoto et al. (2015) between lung tumor spheroids and 2D cultures. Both groups also demonstrated the induction of an apoptotic response in MCTS (Chiarante et al., 2017; Manoto et al., 2013; 2015). In addition, the influence of tumor spheroids size has been explored. In this sense, it has been reported that MCTS with a size of $500 \mu \mathrm{m}$ are more resistant to PDT as compared to MCTS with a size of $250 \mu \mathrm{m}$. Since oxygen pressure and nutrients gradually decrease from the spheroid surface to the core, and PDT is an oxygen dependent therapy, the resistance to PDT seen in spheroids might be due to the reduced amount of oxygen found in the inner region of larger MCTS (Madsen et al., 2006; Manoto et al, 2015). Furthermore, a different gene expression profile was observed after ZnPcSmix PDT of tumor cells grown as monolayers or MCTS, suggesting that different mechanisms of action would be involved in 2D or 3D cell photodamage (Manoto et al., 2017b).

Tumor spheroids were also employed to evaluate the efficacy of different carriers to transport lipophilic ZnPcs. For example, natural membrane vesicles derived from tumor cells loaded with $\mathrm{ZnPc}$ (Lee et al., 2015) or nanocarriers prepared via $\mathrm{ZnPc}$ deposition on $\mathrm{TiO}_{2}$ (Flak et al., 2017) exhibited high potential as drug delivery agents and behaved as efficient phototoxic agents in tumor spheroids.

\subsection{Chicken chorioallantoic membrane assays}


As an alternative in vivo model, tumor cells can be inoculated on the chicken chorioallantoic membrane of fertilized eggs to evaluate the antitumor and antiangiogenic effect of different compounds (Uchida et al., 1987; Shoin et al., 1991). A total occlusion of chorioallantoic membranes vessels and improved photodynamic properties were observed by Chin et al. (2014) after photoactivation of a substituted ZnPc. Obata et al. (2015) demonstrated a significant growth inhibition of B16-F10 tumor cells transplanted to chorioallantoic membranes of chick-embryos irradiated with trifluoroethoxy-ZnPc formulations conjugated with $\beta$-cyclodextrin. Likewise, Kuzyniak et al. $(2016 ; 2017)$, by working with substituted $\mathrm{ZnPcs}$, showed a significant reduction of tumor growth and changes in the vascular network of chorioallantoic membranes.

\subsection{Animal tumor models}

Pharmacokinetics studies and the in vivo efficacy of ZnPcs have been investigated in different murine tumor models. After systemic administration, the phthalocyanine content in tumor and normal tissues has been usually determined by spectrofluorometric analysis. Reddi et al. (1990) evaluated the pharmacokinetic properties of $\mathrm{ZnPc}$ in mice bearing transplanted MS-2 fibrosarcoma and showed an improved selectivity of tumor targeting when low density lipoproteins, instead of liposomes, were employed as drug delivery systems. The slow clearance of $\mathrm{ZnPc}$ by the tumor also suggested that PDT effectiveness can be maintained at relatively long time intervals after administration. As a result, an efficient tumor response was obtained when irradiation was performed at $70 \mathrm{~h}$ after $\mathrm{ZnPc}$ administration. Shopova et al. (1992) also showed the maintenance for $72 \mathrm{~h}$ of the concentration of a liposomal $\mathrm{ZnPc}$ formulation in tumor tissues of hamsters bearing induced or transplanted rhabdomyosarcoma. Similar results were obtained with zinc(II)-naphthalocyanines (ZnNcs) in a Lewis lung carcinoma model (Shopova et al., 1994). 
Different chemical modifications and vehicles have been employed to improve pharmacokinetics in mice, including increased tumor targeting and lower liver and spleen retentions. A study performed with unsubstituted $\mathrm{ZnPc}$ and octapentyl or octadecyl $\mathrm{ZnPc}$ derivatives in fibrosarcoma-bearing mice showed that the maximal concentration of phthalocyanines in tumors was reached at $24 \mathrm{~h}$ post-injection. In addition, a slight increase in the efficiency and selectivity of tumor targeting was obtained upon increasing the length of the alkyl chains protruding from the macrocycle (Fabris et al., 1997; Jori and Fabris, 1998). Thus, both derivatives showed an approximately 50-fold higher concentration in the tumor than in the peritumoral tissue (Fabris et al., 1997). As most of the hydrophobic photosensitizers, Pcs were accumulated in large amounts in the liver and were eliminated from the organism through the bile-gut pathway (Jori, 1990; 2004). When the biodistribution of two substituted $\mathrm{ZnPcs}$ was studied, the monosulphonated analogue $\mathrm{ZnPcF}_{12} \mathrm{~S}_{1}$, which exhibited high phototoxicity in murine tumors, displayed faster hepatic clearance and lower retention by the spleen than the perfluorinated $\mathrm{ZnPcF}_{16}$ (Allémann et al., 1997). Camerin et al. (2010) reported the in vivo PDT efficiency of a gold NP loaded with a hydrophobic ZnPc derivative $(\mathrm{C} 11 \mathrm{Pc})$. This formulation exhibited good tumor selectivity after $24 \mathrm{~h}$ of injection (Camerin et al., 2010). Later, Camerin et al. (2016) described a different delivery vehicle based on the co-self-assembly of $\mathrm{C} 11 \mathrm{Pc}$ and a polyethylene glycol derivative (PEG) onto gold NPs. The incorporation of PEG on the particle surface enhanced the half-life of the conjugate in the serum, improving the in vivo photodynamic therapy of amelanotic melanoma. The pharmacokinetic studies showed that the retention time of the conjugates both in the serum and in the tumor increased as compared with NPs functionalized with $\mathrm{C} 11 \mathrm{Pc}$ alone. The conjugates were eliminated via the bile-gut pathway without observable toxicity. Milla et al. (2009) also showed that a liposomal formulation of a trifluoromethylbenzyloxy $\mathrm{ZnPc}$ was accumulated in spleen, liver and duodenum. In spite of 
these findings, the absence of hepatic toxicity after treatment with substituted ZnPcs was demonstrated by monitoring the hepatic cytochrome P450 activity and the levels of serum glutamic-pyruvic transaminase (Larroque et al., 1996; Yslas et al., 2010). The lack of renal toxicity was also assessed by Yslas et al. (2010) by checking creatinine and urea levels.

Light sources employed in PDT with ZnPcs include lasers between 670 and $700 \mathrm{~nm}$, the wavelengths corresponding to their maximum absorption. ZnPcs and light dosedependent phototoxic action was demonstrated in different in vivo models (Reddi et al., 1990; Allémann et al., 1997). Yslas et al. (2009) evaluated the effect of a tetra-methoxy ZnPc liposomal formulation, employing different light doses. The highest PDT efficacy in a mouse mammary adenocarcinoma model was obtained for the maximal light dose evaluated in the study $\left(210 \mathrm{~J} / \mathrm{cm}^{2}\right)$. Doses mostly employed in vivo for a variety of $\mathrm{ZnPcs}$ are in the range of $150-400 \mathrm{~J} / \mathrm{cm}^{2}$.

In vivo studies demonstrated that, not only the photochemical properties of $\mathrm{ZnPcs}$, but also tumor drug uptake, are important factors for an effective PDT. For instance, different PS tumor concentrations and phototherapeutic effects were observed in vivo for ZnNcs liposomal formulations that exhibited similar quantum yields of ${ }^{1} \mathrm{O}_{2}$-formation in vitro (Shopova et al., 1994). Furthermore, maximum concentrations of ZnPcs were reached $24 \mathrm{~h}$ after intravenous PS administration in different tumor models (Shopova et al., 1992; Allémann et al., 1997; Jori and Fabris, 1998; Yslas et al, 2009; Camerin et al., 2010). In general, the photosensitizing effect of $\mathrm{ZnPcs}$ in vivo was demonstrated by a decrease of tumor volume (Larroque et al., 1996; Yslas et al., 2010; Camerin et al., 2010) and an increase in the survival time of treated animals (Shopova et al., 1992; 1994). In addition, apoptotic pathway (Fabris et al., 1997; Jori and Fabris, 1998; Yslas et al, 2009, 2010; Xu et al., 2014) and random necrosis (Fabris et al., 1997; Jori and Fabris, 1998; Rumie Vittar et al., 2008) have been identified as the main mechanisms responsible for cell death. 
It is interesting to mention that, when the interval of time between drug and light administration was reduced to $1 \mathrm{~h}$ or $3 \mathrm{~h}$, signs of vascular damage were reported. For example, Bremner et al. (1999) evaluated the effects of water-soluble ZnPcs containing neutral, positive and negative side-chains in a murine fibrosarcoma model and showed that tumor growth delay was greater with a $1 \mathrm{~h}$ than with a $24 \mathrm{~h}$ time interval, being the positivecharged $\mathrm{ZnPc}$ the most effective sensitizer. In this study, a reduction in blood flow was shown to be an important factor in PDT. The effect of PDT on vessels was evaluated by Fingar et al. (1993) in Sprague-Dawley rats. Release of eicosanoids, vessel constriction, venule leakage and increased tumor interstitial pressure, as well as tumor reduction, were observed with monosulfonated and tertiary butyl substituted $\mathrm{ZnPcs}$ after light exposure $24 \mathrm{~h}$ post photosensitizer injection. Vascular damage after PDT treatment of a murine melanoma with ZnPc was also reported by Camerin et al. (2010), who confirmed damage of blood capillaries and endothelial cells by electron microscopy. Nevertheless, increased expression of vascular endothelial growth factor (VEGF) and higher microvessel density were detected in animals exposed to PDT. VEGF up-regulation was proposed to be associated with PDT-induced hypoxia (Bhuvaneswari et al., 2007; Das et al., 2010), and may suggest a side effect of PDT promoting tumor recurrence after treatment (Xu et al., 2014).

Novel carriers to transport and efficiently activate ZnPcs have been developed and tested in vivo. Lanthanide-dope upconversion nanoparticles coupled with a $\beta$-carboxy $\mathrm{ZnPc}$ (Wang $\mathrm{M}$ et al., 2014) and other synthetic materials, such as layered double hydroxides bound to unsubstituted $\mathrm{ZnPc}$ or to the octasulfonate $\mathrm{ZnPc}$, showed to be efficient PDT agents for tumor growth inhibition (Liang et al., 2014b; Li et al., 2017). A tumor-pH-responsive photosensitizer, prepared by conjugating ZnPc with 2,4,6-tris (N, N-dimethylaminomethyl) phenoxy, showed not only to ablate tumor cells in 4T1 cells-bearing mice, but also presented 
fluorescence imaging of tumor sites, suggesting that this Pc may be employed for tumor treatment and theranostics (Yan et al., 2018a).

To sum up, all the in vivo studies provided strong evidences for the clinical application of $\mathrm{ZnPcs}$ and its derivatives formulations in PDT for cancer treatment. As it was mentioned, critical parameters must be adjusted to obtain a proper PDT efficacy, such as the optimal PS dose, the interval between photosensitizer administration and time of irradiation, light dose and light dose rate.

\section{Toxicity studies and clinical trials}

The first clinical trials were performed with the $\mathrm{ZnPc}$ tetrasulfonate $\left(\mathrm{ZnPcS}_{4}\right)$ for use in veterinary medicine. $\mathrm{ZnPcS}_{4}$ was initially administered to Swiss Webster mice to assess acute toxicity. Doses $>100 \mathrm{mg} / \mathrm{kg}$ produced renal tubular nephrosis, resulting in acute toxicity and mortality. Based on these data, a phase I clinical trial of $\mathrm{ZnPcS}_{4}$-based PDT against spontaneous tumors in dogs was started at a dose of $0.25 \mathrm{mg} / \mathrm{kg}$ and irradiation with $675 \mathrm{~nm}$ light $\left(100 \mathrm{~J} / \mathrm{cm}^{2}\right) 24 \mathrm{~h}$ after PS intravenous injection (Borgatti-Jeffreys et al., 2005). This study demonstrated tumor response using doses of $0.25 \mathrm{mg} / \mathrm{kg}$ and no adverse effects were observed with $\mathrm{ZnPcS}_{4}$ doses up to $2 \mathrm{mg} / \mathrm{kg}$. Then, a new phase I clinical trial with an enlarged cohort of dogs was performed (Borgatti-Jeffreys et al., 2007). The PDT efficacy was confirmed in both mesenchymal and epithelial tumors. Another study showed partial responses or complete remissions of squamous cell carcinoma of the head and neck in dogs and cats treated with $\mathrm{ZnPcS}_{4}$-PDT with no prolonged cutaneous photosensitization or adverse effects (Lucroy, 2006).

In parallel, a repeated-dose toxicity study of ZnPc-based-PDT was performed in Wistar rats. The intravenous administration of di-sulfo-di-phthalimidomethyl ZnPc, known as Photocyanine, and irradiation with a $670 \mathrm{~nm}$ laser light induced liver abnormalities and 
pigmentation in several important organs at $4 \mathrm{mg} / \mathrm{kg} / \mathrm{day}$. The no-observed-adverse-effect levels were $1.0 \mathrm{mg} / \mathrm{kg}$ in Wistar rats (Zhang et al., 2006) and $1.5 \mathrm{mg} / \mathrm{kg}$ in dogs (Liu et al., 2007). Characterization studies with Photocyanine were performed in order to determine optimal light dose and drug dosage in a murine sarcoma S180 model. An inhibitory effect on tumor growth was observed for $2 \mathrm{mg} \mathrm{ZnPc/kg}$ when irradiation doses using a 670-nm laser increased in the range of $36-144 \mathrm{~J} / \mathrm{cm}^{2}$. Vertical resection of irradiated tumors showed that the depth of local tissue necrosis was 5.7-7.5 mm (Xue et al., 2011).

\section{ZnPc-PDT combined strategies}

In the last years several works have focused on the employment of combined therapies in order to overcome the high failure rate of single-agent or single-regimen therapy. Multiple drug combinations for cancer aim to exploit the additive or synergistic effects obtained from the action of two species, resulting in an improved antitumor efficacy, reduced side effects, and retarded drug resistance. Thus, PDT coupled with chemotherapy agents has proven to be a promising combination treatment for some kinds of tumors (Brodin et al., 2015). The encapsulation of $\mathrm{ZnPc}$ and doxorubicin (DOX) into nanovehicles linked to folic acid achieved a synergistic chemotherapy-PDT in tumor cells overexpressing folic acid receptors (Liang et al., 2015; Flak et al., 2017; Huang et al., 2018). ZnPc and DOX were also conjugated through acid-labile and redox-responsive disulfide linkers in polymeric micelles. The observation of DOX fluorescence in the nucleus and $\mathrm{ZnPc}$ in the cytoplasm demonstrated that acidic and reducing intracellular environments could trigger the release of drugs by cleaving the linkers (Gao and Lo, 2018). A synergistic cytotoxicity was therefore found for certain DOX:ZnPc ratios in tumor-bearing mice. $\mathrm{ZnPc}$ was also covalently conjugated with DOX by the sequence Thr-Ser-Gly-Pro. In this case, although the conjugation of $\mathrm{ZnPc}$ with DOX led to the inhibition of the photodynamic activity of the PS 
and reduced DOX cytotoxicity, the peptide was sensitive to the activity of a protease highly expressed on cancer-associated fibroblasts. As a consequence, an enhanced cytotoxicity was observed upon cleavage and illumination (Ke et al., 2017). Synergistic anticancer effects of PDT and chemotherapy were also demonstrated by the combination of $\mathrm{ZnPc}$ with docetaxel (Conte et al., 2013) or paclitaxel (Wang Y et al., 2018b). In addition, the simultaneous administration of two PSs, such as $\mathrm{ZnPc}$ and a cationic porphyrin, led to a potentiated antitumor effect in mice bearing amelanotic melanoma cells (Acedo et al., 2014). ZnPc-PDT has also been efficiently combined with a Bcl-2 inhibitor (Liu et al., 2017), an autophagy inhibitor (Yu et al., 2019), a cell cycle inhibitor (Yan et al., 2018b) or an immunostimulant agent (Marrache et al., 2013). In addition, the combination of the autophagy inhibitor 3methyladenine with ZnPc-PDT as an strategy for osteosarcoma treatment down-regulated the expression levels of death ligand-1 (PD-L1), inhibiting tumor growth in a model of tumor metastasis (Yu et al., 2019). Recent studies have pointed out the role of PD-1 and its ligand PD-L1 as the most critical immune checkpoint blocking T-cell response and promoting tumor growth (Herbst et al., 2014; Dermani et al., 2019). Thus, further studies of combined therapy with immune checkpoint blockade and ZnPc-PDT will broaden the possibility of enhancing the immune anti-tumor response.

When ZnPcs were incorporated into systems employed for hyperthermia generation, such as carbon nanohorns and gold nanorods, enhanced PDT efficiency was obtained. In these systems, laser irradiation was useful to simultaneously activate the PS and hyperthermia surfaces (Zhang et al., 2008; Freitas et al., 2017). Similarly, magnetohyperthermia and PDT with ZnPcs incorporated into magnetic nanoemulsions or nanoparticles led to significant tumor regression (Primo et al., 2008; Bolfarini et al., 2012; Feuser et al., 2015). Therefore, the development of multiple drug combinations or new 
strategies will undoubtedly contribute to finding better therapeutic options for cancer treatment in the near future.

\section{Conclusions}

Based on the properties that should posses an ideal PS, phthalocyanines have been widely employed as second generation sensitizers. In particular, many efforts have been made to develop medicinal Pcs with therapeutic efficacy. In the field of ZnPcs, the photophysical and photochemical properties, subcellular localization, phototoxic activity, mechanisms of cell death and improved targeting to tumor tissues have been the main topics explored. The simultaneous localization of some $\mathrm{ZnPcs}$ in lysosomes/mitochondria or lysosomes/ER seems to be optimal for cell photodamage and its potential as therapeutic agents. Although the most extensive mode of cell death characterized so far has been apoptosis, it is necessary to continue investigating the contribution of other death modalities, such as necrosis, autophagy or even paraptosis, a type of cell death not yet studied for ZnPcs. The search of new possible mechanisms of action may consequently contribute to novel applications for single or combined ZnPcs treatments. Up to this moment, there is an immediate need to increase the number of clinical trials evaluating ZnPcs. As a result, it would be possible to confirm preclinical studies and orientate future research. PDT has much to offer to cancer treatment due to its unique combination of tumor cytotoxicity, vessel occlusion and immune response with minimal side effects. A deeper understanding of the effects of PDT with ZnPcs could enable in the future the improvement of currently used protocols and the treatment of an increased number of oncological diseases.

\section{Conflict of interest}

The authors declare no conflict of interest. 


\section{Acknowledgments}

This work was supported by grants from Consejo Nacional de Investigaciones Científicas y Técnicas (CONICET, PIP 0154: "Propiedades y mecanismo de acción de nuevos agentes antitumorales: péptidos quiméricos del IFN alfa, ftalocianinas de Zn(II) y derivados sintéticos de penicilinas"), Universidad de Buenos Aires (UBACYT 20020170100041: "Mecanismos de acción in vitro e in vivo de novedosos agentes antitumorales. Implementación de estrategias terapéuticas innovadoras”). We apologize to all researchers whose crucial contributions in the field of PDT with ZnPcs were not mentioned due to limitations in space.

\section{References}

Abrahamse, H., Kruger, C.A., Kadanyo, S., Mishra, A., 2017. Nanoparticles for advanced photodynamic therapy of cancer. Photomedicine and Laser Surgery 35, 581-588. 
Acedo, P., Stockert, J.C., Cañete, M., Villanueva, A., 2014. Two combined photosensitizers: a goal for more effective photodynamic therapy of cancer. Cell Death Dis. 5:e1122. doi: 10.1038/cddis.2014.77.

Agostinis, P., Berg, K., Cengel, K.A., Foster, T.H., Girotti, A.W., Gollnick, S.O., Hahn, S.M., Hamblin, M.R., Juzeniene, A., Kessel, D., Korbelik, M., Moan, J., Mroz, P., Nowis, D., Piette, J., Wilson, B.C., Golab, J., 2011. Photodynamic therapy of cancer: an update. CA: A Cancer Journal for Clinicians 61(4), 250-281.

Alexandratou, E., Yova, D., Loukas, S., 2005. A confocal microscopy study of the very early cellular response to oxidative stress induced by zinc phthalocyanine sensitization. Free Radic. Biol. Med. 39(9), 1119-1127.

Allémann, E., Brasseur, N., Kudrevich, S.V., La Madeleine, C., van Lier, J.E., 1997. Photodynamic activities and biodistribution of fluorinated zinc phthalocyanine derivatives in the murine EMT-6 tumour model. Int J Cancer. 72(2), 289-294.

Allison, R.R., Sibata, C.H., 2010. Oncologic photodynamic therapy photosensitizers: a clinical review. Photodiagnosis and Photodynamic Therapy 7, 61-75.

Bhuvaneswari, R., Yuen, G.Y., Chee, S.K., Olivo, M., 2007. Hypericin-mediated photodynamic therapy in combination with Avastin (bevacizumab) improves tumor response by downregulating angiogenic proteins. Photochem Photobiol Sci 2007; 6: 1275-1283.

Bolfarini, G.C., Siqueira-Moura, M.P., Demets, G.J., Morais, P.C., Tedesco, A.C., 2012. In vitro evaluation of combined hyperthermia and photodynamic effects using magnetoliposomes loaded with cucurbituril zinc phthalocyanine complex on melanoma. J Photochem Photobiol B. 115, 1-4. doi: 10.1016/j.jphotobiol.2012.05.009.

Borgatti-Jeffreys, A., Hooser, S.B., Miller, M.A., Thomas, R.M., deGortari, A., Lucroy, M.D., 2005. Preclinical evaluation of zinc phthalocyanine tetrasulfonate-based PDT. Proc. of SPIE 5686, 624-630. doi: 10.1117/12.588378.

Borgatti-Jeffreys, A., Hooser, S.B., Miller, M.A., Lucroy, M.D., 2007. Phase I clinical trial of the use of zinc phthalocyanine tetrasulfonate as a photosensitizer for photodynamic therapy in dogs. Am J Vet Res. 68(4), 399-404.

Boyle, R.W., Paquette, B., van Lier, J.E., 1992. Biological activities of phthalocyanines. XIV. Effect of hydrophobic phthalimidomethyl groups on the in vivo phototoxicity and mechanism of photodynamic action of sulphonated aluminium phthalocyanines. Br. J. Cancer 65(6), 813-817.

Braun, A., Tcherniac, J., 1907. Über die Produkte der Einwirkung von Acetanhy- did auf Phthalamid. Ber. Deut. Chem. Ges. 40, 2709-2714. 
Bremner, J.C., Wood, S.R., Bradley, J.K., Griffiths, J., Adams, G.E., Brown, S.B., 1999. ${ }^{31}$ P magnetic resonance spectroscopy as a predictor of efficacy in photodynamic therapy using differently charged zinc phthalocyanines. Br J Cancer 81(4), 616-621.

Brodin, N.P., Guha, C., Tomé, W.A., 2015. Photodynamic therapy and its role in combined modality anticancer treatment. Technol Cancer Res Treat. 14(4), 355-68. doi: $10.1177 / 1533034614556192$.

Broekgaarden, M., Kos, M., Jurg, F.A., van Beek, A.A., van Gulik, T.M., Heger, M., 2015. Inhibition of NF- $\kappa \mathrm{B}$ in tumor cells exacerbates immune cell activation following photodynamic therapy. Int J Mol Sci. 16(8), 19960-19977. doi: 10.3390/ijms160819960.

Broekgaarden, M., van Vught, R., Oliveira, S., Roovers, R.C., van Bergen en Henegouwen, P.M., Pieters, R.J., Van Gulik, T.M., Breukink, E., Heger, M., 2016a. Site-specific conjugation of single domain antibodies to liposomes enhances photosensitizer uptake and photodynamic therapy efficacy. Nanoscale. 8(12), 6490-6494. doi: 10.1039/c6nr00014b.

Broekgaarden, M., Weijer, R., Krekorian, M, van den Ijssel, B., Kos, M., Alles, L.K., van Wijk A.C., Bikadi, Z., Hazai, E., van Gulik, T.M, Heger, M., 2016b. Inhibition of hypoxiainducible factor 1 with acriflavine sensitizes hypoxic tumor cells to photodynamic therapy with zinc phthalocyanine-encapsulating cationic liposomes. Nano Research. 9(6), 16391662.

Buytaert, E., Dewaele, M., Agostinis, P., 2007. Molecular effectors of multiple cell death pathways initiated by photodynamic therapy. Biochim Biophys Acta. 1776(1), 86-107.

Camerin, M., Magaraggia, M., Soncin, M., Jori, G., Moreno, M., Chambrier, I., Cook, M.J., Russell, D.A., 2010. The in vivo efficacy of phthalocyanine-nanoparticle conjugates for the photodynamic therapy of amelanotic melanoma. Eur J Cancer. 46(10), 1910-1918. doi: 10.1016/j.ejca.2010.02.037.

Camerin, M., Moreno, M., Marín, M.J., Schofield, C.L., Chambrier, I., Cook, M,J., Coppellotti, O., Jori, G., Russell, D.A. 2016. Delivery of a hydrophobic phthalocyanine photosensitizer using PEGylated gold nanoparticle conjugates for the in vivo photodynamic therapy of amelanotic melanoma. Photochem Photobiol Sci. 15(5):618-25. doi: 10.1039/c5pp00463b.

Castano, A.P., Mroz, P., Hamblin, M.R., 2006. Photodynamic therapy and anti-tumour immunity. Nat. Rev. Cancer 6, 535-545.

Chiarante, N., García Vior, M.C., Awruch, J., Marino, J., Roguin, L.P., 2017. Phototoxic action of a zinc(II) phthalocyanine encapsulated into poloxamine polymeric micelles in $2 \mathrm{D}$ and 3D colon carcinoma cell cultures. J. Photochem. Photobiol. B 170, 140-151. 
Chiarante, N., García Vior, M.C., Rey, O., Marino, J., Roguin, L.P., 2018. Lysosomal permeabilization and endoplasmic reticulum stress mediate the apoptotic response induced after photoactivation of a lipophilic zinc(II) phthalocyanine. Int J Biochem Cell Biol. 103, 89-98. doi: 10.1016/j.biocel.2018.08.009.

Chin, Y., Lim, S.H., Zorlu, Y., Ahsen, V., Kiew, L.V., Chung, L.Y., Dumoulin, F., Lee, H.B., 2014. Improved photodynamic efficacy of $\mathrm{Zn}$ (II) phthalocyanines via glycerol substitution. PLoS One 9(5):e97894. doi: 10.1371/journal.pone.0097894.

Chiu, S.M., Xue, L.Y., Lam, M., Rodriguez, M.E., Zhang, P., Kenney, M.E., Nieminen, A.L., Oleinick, N.L., 2010. A requirement for bid for induction of apoptosis by photodynamic therapy with a lysosome- but not a mitochondrion-targeted photosensitizer. Photochemistry and Photobiology 86, 1161-1173.

Cirman, T., Oresić, K., Mazovec, G.D., Turk, V., Reed, J.C., Myers, R.M., Salvesen, G.S., Turk, B., 2004. Selective disruption of lysosomes in HeLa cells triggers apoptosis mediated by cleavage of Bid by multiple papain-like lysosomal cathepsins. J Biol Chem. 279(5), 35783587. Epub 2003 Oct 27.

Colussi, V.C., Feyes, D.K., Mulvihill, J.W., Li, Y.S., Kenney, M.E., Elmets, C.A., Oleinick, N.L., Mukhtar, H., 1999. Phthalocyanine 4 (Pc 4) photodynamic therapy of human OVCAR3 tumor xenografts. Photochem. Photobiol. 69, 236-241.

Conte, C., Ungaro, F., Maglio, G., Tirino, P., Siracusano, G., Sciortino, M.T., Leone, N., Palma, G., Barbieri, A., Arra, C., Mazzaglia, A., Quaglia, F., 2013. Biodegradable core-shell nanoassemblies for the delivery of docetaxel and $\mathrm{Zn}$ (II)-phthalocyanine inspired by combination therapy for cancer. J Control Release. 167(1), 40-52. doi: 10.1016/j.jconrel.2012.12.026.

Cristóbal, J., Stockert, J.C., Villanueva, A., Rello-Varona, S., Juarranz, A., Cañete, M., 2006. Caspase-2: a possible trigger of apoptosis induced in A-549 tumor cells by $\mathrm{ZnPc}$ photodynamic treatment. Int. J. Oncol. 28(5), 1057-1063.

Cui, S., Yin, D., Chen, Y., Di, Y., Chen, H., Ma, Y., Achilefu, S., Gu, Y., 2013. In vivo targeted deep-tissue photodynamic therapy based on near-infrared light triggered upconversion nanoconstruct. ACS Nano. 7(1), 676-688. doi: 10.1021/nn304872n.

Dai, L., Yu, Y., Luo, Z., Li, M., Chen, W., Shen, X., Chen, F., Sun, Q., Zhang, Q., Gu, H., Cai, K., 2016. Photosensitizer enhanced disassembly of amphiphilic micelle for ROSresponse targeted tumor therapy in vivo. Biomaterials. 104, 1-17. doi: 10.1016/j.biomaterials.2016.07.002. 
Das, R., Jahr, H., van Osch, G.J., Farrell, E., 2010. The role of hypoxia in MSCs: Considerations for regenerative medicine approaches. Tissue Eng Part B Rev. 16(2), 159168. doi: 10.1089/ten.TEB.2009.0296.

de Oliveira, C.A., Kohn, L.K., Antonio, M.A., Carvalho, J.E., Moreira, M.R., Machado, A,E, Pessine, F.B., 2010. Photoinactivation of different human tumor cell lines and sheep red blood cells in vitro by liposome-bound $\mathrm{Zn}$ (II) Phthalocyanine: Effects of cholesterol. J Photochem Photobiol B. 100(2), 92-99. doi: 10.1016/j.jphotobiol.2010.05.006.

Debele, T.A., Mekuria, S.L., Tsai, H.C., 2017. A pH-sensitive micelle composed of heparin, phospholipids, and histidine as the carrier of photosensitizers: Application to enhance photodynamic therapy of cancer. Int $\mathbf{J}$ Biol Macromol. 98, 125-138. doi: 10.1016/j.ijbiomac.2017.01.103.

Detty, M.R., Gibson, S.L., Wagner, S.J., 2004. Current clinical and preclinical photosensitizers for use in photodynamic therapy. J. Med. Chem. 47, 3897-3915.

Diamond, I., Granelli, S.G., McDonagh, A.F., Nielsen, S., Wilson, C.B., Jaenicke, R., 1972. Photodynamic therapy of malignant tumours. Lancet 2, 1175-1177.

Dougherty, T.J., Grindey, G.B., Weishaupt, K.R., Boyle D., 1975. Photo-radiation therapy II. Cure of animal tumours with haematoporphyrin and light. Journal of the National Cancer Institute 55, 115-121.

Dougherty, T.J., Kaufman, J.E., Goldfarb, A., Weishaupt, K.R., Boyle, D., Mittlemen, A., 1978. Photoradiation therapy for the treatment of malignant tumours. Cancer Research 38, 2628-2635.

Doustvandi, M.A., Mohammadnejad, F., Mansoori, B., Mohammadi, A., Navaeipour, F., Baradaran, B., Tajalli, H., 2017. The interaction between the light source dose and caspasedependent and -independent apoptosis in human SK-MEL-3 skin cancer cells following photodynamic therapy with zinc phthalocyanine: A comparative study. J Photochem Photobiol B. 176, 62-68. doi: 10.1016/j.jphotobiol.2017.09.020.

Dermani, F.K., Samadi, P., Rahmani, G., Kohlan, A.K., Najafi, R., 2019. PD-1/PD-L1 immune checkpoint: Potential target for cancer therapy. J Cell Physiol. 234(2), 1313-1325. doi: $10.1002 /$ jcp. 27172.

Duan, W., Lo, P.C., Duan, L., Fong, W.P., Ng, D.K., 2010. Preparation and in vitro photodynamic activity of amphiphilic zinc(II) phthalocyanines substituted with 2(dimethylamino)ethylthio moieties and their N-alkylated derivatives. Bioorg. Med. Chem. 18(7), 2672-2677. 
Dube, E., Oluwole, D.O. Prinsloo E., Nyokong, T., 2018. Gold-chitosan composite with low symmetry zinc phthalocyanine for enhanced singlet oxygen generation and improved photodynamic therapy activity. New J. Chem. 42, 10214-10225.

Engbreht, B.W., Menon, C., Kahur, A.V., Hahn, S.M., Fraker, D.L., 1999. Photofrinmediated photodynamic therapy induces vascular occlusion and apoptosis in a human sarcoma xerograft model. Cancer Res. 59, 4334-4342.

Ezquerra Riega, S.D., Chiarante, N., Valli, F., Marino, J., Roguin, L.P., Awruch, J., García Vior, M.C., 2018. Novel hydro- and lipo-philic selenium zinc(II) phthalocyanines: Synthesis, photophysical properties and photodynamic effects on CT26 colon carcinoma cells. Dyes Pigm. 156, 133-139. doi: 10.1016/j.dyepig.2018.03.067.

Fabris, C., Ometto, C., Milanesi, C., Jori, G., Cook, M.J., Russell, D.A., 1997. Tumourlocalizing and tumour-photosensitizing properties of zinc(II)-octapentyl-phthalocyanine. J Photochem Photobiol B. 39(3), 279-284.

Fabris, C., Valduga, G., Miotto, G., Borsetto, L., Jori, G., Garbisa, S., et al., 2001. Photosensitization with zinc (II) phthalocyanine as a switch in the decision between apoptosis and necrosis. Cancer Res. 15, 7495-7500.

Fabris, C., Soncin, M., Miotto, G., Fantetti, L., Chiti, G., Dei, D., Roncucci, G., Jori, G., 2006. $\mathrm{Zn}(\mathrm{II})$-phthalocyanines as phototherapeutic agents for cutaneous diseases. Photosensitization of fibroblasts and keratinocytes. J Photochem Photobiol B. 83(1), 48-54. Feuser, P.E., Fernandes, A.C., Nele, M., Viegas Ada, C., Ricci-Junior, E., Tedesco, A.C., Sayer, C., de Araújo, P.H., 2015. Simultaneous encapsulation of magnetic nanoparticles and zinc phthalocyanine in poly(methyl methacrylate) nanoparticles by miniemulsion polymerization and in vitro studies. Colloids Surf B Biointerfaces 135, 357-364. doi: 10.1016/j.colsurfb.2015.07.067.

Fingar, V.H., Wieman, T.J., Karavolos, P.S., Doak, K.W., Ouellet, R., van Lier, J.E., 1993. The effects of photodynamic therapy using differently substituted zinc phthalocyanines on vessel constriction, vessel leakage and tumor response. Photochem Photobiol. 58(2), 251258.

Flak, D., Yate, L., Nowaczyk, G., Jurga, S., 2017. Hybrid ZnPc@TiO2 nanostructures for targeted photodynamic therapy, bioimaging and doxorubicin delivery. Mater Sci Eng C Mater Biol Appl. 78, 1072-1085. doi: 10.1016/j.msec.2017.04.107.

Freitas, L.F., Hamblin, M.R., Anzengruber, F., Perussi, J.R., Ribeiro, A.O., Martins, V.C.A., Plepis, A.M.G., 2017. Zinc phthalocyanines attached to gold nanorods for simultaneous 
hyperthermic and photodynamic therapies against melanoma in vitro. J Photochem Photobiol B. 173, 181-186. doi: 10.1016/j.jphotobiol.2017.05.037.

Fujishiro, T., Nonoguchi, N., Pavliukov, M., Ohmura, N., Park, Y., Kajimoto, Y., Ishikawa, T., Nakano, I., Kuroiwa, T., 2018. 5-aminolevulinic acid-mediated photodynamic therapy can target human glioma stem-like cells refractory to antineoplastic agents. Photodiagnosis and Photodynamic Therapy S1572-1000(18)30185-6.

Galluzzi, L., Maiuri, M.C., Vitale, I., Zischka, H., Castedo, M., Zitvogel, L., Kroemer, G., 2007. Cell death modalities: classification and pathophysiological implications. Cell Death Differ. 14(7):1237-1243.

Galluzzi, L., Vitale, I., Abrams, J.M., Alnemri, E.S., Baehrecke, E.H., Blagosklonny, M.V., et al., 2012. Molecular definitions of cell death subroutines: recommendations of the Nomenclature Committee on Cell Death 2012. Cell Death Differ. 19, 107-120. doi: 10.1038/cdd.2011.96.

Gao, D., Lo, PC., 2018. Polymeric micelles encapsulating pH-responsive doxorubicin prodrug and glutathione-activated zinc(II) phthalocyanine for combined chemotherapy and photodynamic therapy. Journal of Controlled Release 282, 46-61.

Garcia, A.M., Alarcon, E., Muñoz, M., Scaiano, J.C., Edwards, A.M., Lissi, E., 2011. Photophysical behaviour and photodynamic activity of zinc phthalocyanines associated to liposomes. Photochem Photobiol Sci. 10(4), 507-514. doi: 10.1039/c0pp00289e.

Garcia, A., de Alwis Weerasekera, H., Pitre, S.P., McNeill, B., Lissi, E., Edwards, A.M., Alarcon, E.I., 2016. Photodynamic performance of zinc phthalocyanine in HeLa cells: A comparison between DPCC liposomes and BSA as delivery systems. J. Photochem. Photobiol. B. 163, 385-390.

García Calavia, P., Chambrier, I., Cook, M.J., Haines, A.H., Field, R.A., Russell, D.A., 2018. Targeted photodynamic therapy of breast cancer cells using lactose-phthalocyanine functionalized gold nanoparticles. J Colloid Interface Sci. 512, 249-259. doi: 10.1016/j.jcis.2017.10.030.

García Vior, M.C., Dicelio, L.E., Awruch, J., 2009. Synthesis and properties of phthalocyanine zinc(II) complexes replaced with oxygen and sulfur linked adamantane moieties. Dyes Pigm. 83, 375-380. doi: 10.1016/j.dyepig.2009.06.006.

García Vior, M.C., Marino, J., Roguin, L.P., Sosnik, A., Awruch, J., 2013. Photodynamic effects of zinc(II) phthalocyanine-loaded polymeric micelles in human nasopharynx $\mathrm{KB}$ carcinoma cells. Photochemistry and Photobiology 89, 492-500. 
García Vior, M.C., Awruch, J., Dicelio, L.E., Diz, V., 2019. 2(3), 9(10), 16(17), 23(24)tetrakis[(3-mercapto)propoxy]phthalocyaninate zinc (II)/gold nanoparticle conjugates: Synthesis and photophysical properties. J. Photochem. Photobiol. A: Chem. 368, 242-247. https://doi.org/10.1016/j.jphotochem.2018.09.024.

Gauna, G.A., Marino, J., García Vior, M.C., Roguin, L.P., 2011. Synthesis and comparative photodynamic properties of two isosteric alkyl substituted zinc(II) phthalocyanines. European Journal of Medicinal Chemistry 46, 5532-5539.

Ge, Y., Weng, X., Tian, T., Ding, F., Huang, R., Yuan, L., Wu, J., Wang, T., Guo, P., Zhou, X., 2013. A mitochondria-targeted zinc(II) phthalocyanine for photodynamic therapy. RSC Advances 3, 12839-12846.

Gomes, A.T.P.C., Neves, M.G.P.M.S., Cavaleiro, J.A.S., 2018. Cancer, Photodynamic Therapy and Porphyrin-Type Derivatives. Annals of the Brazilian Academy of Sciences 90(1,2), 993-1026.

Grütter, M.G., 2000. Caspases: key players in programmed cell death. Curr Opin Struct Biol. 10(6), 649-655.

Guo, H., Qian, H., Idris, N.M., Zhang, Y., 2010. Singlet oxygen-induced apoptosis of cancer cells using upconversion fluorescent nanoparticles as a carrier of photosensitizer. Nanomedicine. 6(3), 486-495. doi: 10.1016/j.nano.2009.11.004.

Hanack, M., Schmid, G., Sommerauer, M., 1993. Chromatographic Separation of the Four Possible Structural Isomers of a Tetrasubstituted Phthalocyanine: Tetrakis(2ethylhexyloxy)phthalocyaninatonickel(II). Angewandte Chemie International 32, 14221424. doi:10.1002/anie.199314221.

Haywood-Small, S.L., Vernon, D.I., Griffiths, J., Schofield, J., Brown, S.B., 2006. Phthalocyanine-mediated photodynamic therapy induces cell deathand a G0/G1 cell cycle arrest in cervical cancer cells. Biochem. Biophys. Res. Comm. 339, 569-576. doi: 10.1016/j.bbrc.2005.11.046.

Henderson, B.W., Dougherty, T.J., 1992. How does photodynamic therapy work? Photochemistry and Photobiology 55, 145-157.

Herbst RS, Soria JC, Kowanetz M, et al., 2014. Predictive correlates of response to the antiPD-L1 antibody MPDL3280A in cancer patients. Nature. 515(7528), 563-567. doi: 10.1038/nature14011. 
Hou, B., Zheng, B., Gong, X., Wang, H., Wang, S., Liao, Z., Li, X., Zhang, X., Chang, J., 2015. A UCN@mSiO2@cross-linked lipid with high steric stability as a NIR remote controlled-release nanocarrier for photodynamic therapy. J. Mater. Chem. B. 3, 3531-3540. Hu, M., Brasseur, N., Yildiz, S.Z., van Lier, J.E., Leznoff, C.C., 1998. Hydroxyphthalocyanines as potential photodynamic agents for cancer therapy. J Med Chem. 41(11), 1789-1802.

Huang, H., Chen, Y., Wu, Y., 2005. Mitochondria-dependent apoptosis induced by a novel amphipathic photochemotherapeutic agent $\mathrm{ZnPcS}_{2} \mathrm{P}_{2}$ in $\mathrm{HL60}$ cells. Acta Pharmacologica Sinica $26(9), 1138-1144$.

Huang, Y., Yu, H., Lv, H., Zhang, H., Ma, D., Yang, H., Xie, S., Peng, Y. 2016. Triblock copolymers encapsulated poly (aryl benzyl ether) dendrimer zinc(II) phthalocyanine nanoparticles for enhancement in vitro photodynamic efficacy. Photodiagnosis Photodyn. Ther. 16, 124-131.

Huang, Z., Xiao, H., Lu, X., Yan, W., Ji, Z., 2018. Enhanced photo/chemo combination efficiency against bladder tumor by encapsulation of DOX and ZnPC into in situ-formed thermosensitive polymer hydrogel. Int $\mathrm{J}$ Nanomedicine. 13, 7623-7631. doi: 10.2147/IJN.S179226. eCollection 2018.

Ichinose, S., Usuda, J., Hirata, T., Inoue, T., Ohtani, K., et al., 2006. Lysosomal cathepsin initiates apoptosis, which is regulated by photodamage to Bcl-2 at mitochondria in photodynamic therapy using a novel photosensitizer, ATX-s10 (Na). Int J Oncol. 29(2), 349355.

Ikeuchi, T. Mack, J., Nyokong, T., Kobayashi, N., Kimura, M., 2016. Aggregation control of robust water-soluble zinc(II) phthalocyanine-based photosensitizers. Langmuir 32, 1198011985. doi :10.1021/acs.langmuir.6b03552.

Jori, G., 1990. Photodynamic therapy: a novel approach to the treatment of tumours. Bull. Mol. Biol. Med. 15, 73-83.

Jori, G., 1992. Far-red-absorbing photosensitizers: their use in the photodynamic therapy of tumours. J. Photochem. Photobiol. A: Chem. 62(3), 371-378.

Jori, G., Fabris, C., 1998. Relative contributions of apoptosis and random necrosis in tumour response to photodynamic therapy: effect of the chemical structure of $\mathrm{Zn}$ (II)phthalocyanines. J Photochem Photobiol B. 43(3), 181-185.

Jori, G., 2004. Photodynamic therapy: basic and preclinical aspects. In: Horspool W, Lenci F, editors. Organic photochemistry and photobiology. Boca Raton, FL: CRC Press; 2004. p. 146-1-146-10. 
Kaufmann, S.H., Hengartner, M.O., 2001. Programmed cell death: alive and well in the new millennium. Trends Cell Biol. 11(12), 526-534.

Ke, M., Chen, S., Peng, X., Zheng, Q., Zheng, B., Yeh, C., Huang J., 2017. A tumor-targeted activatable phthalocyanine-tetrapeptide-doxorubicin conjugate for synergistic chemophotodynamic therapy. Eur. J. Med. Chem. 127, 200-209. doi: 10.1016/j.ejmech.2016.12.056.

Ke, M.R., Huang, J.D., Weng, S.M., 2009. Comparison between non-peripherally and peripherally tetra-substituted zinc (II) phthalocyanines as photosensitizers: Synthesis, spectroscopic, photochemical and photobiological properties. J. Photochem. Photobiol. A: Chem. 201, 23-31. doi: 10.1016/j.jphotochem.2008.09.011.

Kessel, D., 2004. Correlation between subcellular localization and photodynamic efficacy. Journal of Porphyrins and Phthalocyanines 8, 1009-1014.

Kessel, D., 2018. Apoptosis, Paraptosis and Autophagy: Death and Survival Pathways Associated with Photodynamic Therapy. Photochemistry and Photobiology 95(1), 119-125. Kessel, D., Oleinick, N.L., 2018. Cell Death Pathways Associated with Photodynamic Therapy: An Update. Photochemistry and Photobiology 94, 213-218.

Kessel, D., 2019. Pathways to Paraptosis after ER Photodamage in OVCAR-5 cells. Photochem Photobiol. doi: 10.1111/php.13103.

Kiew, L.V., Cheah, H.Y., Voon, S.H., Gallon, E., Movellan, J., Ng, K.H., Alpugan, S., Lee, H.B., Dumoulin, F., Vicent, M.J., Chung, L.Y., 2017. Near-infrared activatable phthalocyanine-poly-L-glutamic acid conjugate: increased cellular uptake and light-dark toxicity ratio toward an effective photodynamic cancer therapy. Nanomedicine 13(4), 14471458 .

Kim, J., Santos, O.A., Park, J.H., 2014. Selective photosensitizer delivery into plasma membrane for effective photodynamic therapy. J Control Release. 191, 98-104. doi: 10.1016/j.jconrel.2014.05.049.

Kou, J., Dou, D., Yang, L., 2017. Porphyrin photosensitizers in photodynamic therapy and its applications. Oncotarget 8(46), 81591-81603.

Kudarha, R.R., Sawant, K.K., 2017. Albumin based versatile multifunctional nanocarriers for cancer therapy: Fabrication, surface modification, multimodal therapeutics and imaging approaches. Materials Science and Engineering C: Materials for Biological Applications 81, 607-626.

Kuzyniak, W., Ermilov, E.A., Atilla, D., Gürek, A.G., Nitzsche, B., Derkow, K., Hoffmann, B., Steinemann, G., Ahsen, V., Höpfner, M., 2016. Tetra-triethyleneoxysulfonyl substituted 
zinc phthalocyanine for photodynamic cancer therapy. Photodiagnosis Photodyn Ther. 13, 148-157. doi: 10.1016/j.pdpdt.2015.07.001.

Kuzyniak, W., Schmidt, J., Glac W., Berkholz, J., Steinemann, G., Hoffmann, B., Ermilov, E.A., Gürek, A.G., Ahsen V, Nitzsche B, Höpfner M., 2017. Novel zinc phthalocyanine as a promising photosensitizer for photodynamic treatment of esophageal cancer.Int $\mathbf{J}$ Oncol. 50(3), 953-963. doi: 10.3892/ijo.2017.3854.

Lagorio, M.G., Dicelio, L.E., San Roman, E.J., 1993. Visible and near-IR spectroscopic and photochemical characterization of substituted metallophthalocyanines. Photochem. Photobiol. A: Chem. 72, 153-161. doi: 10.1016/1010-6030(93)85022-Z.

Lamch, Ł., Kulbacka, J., Pietkiewicz, J., Rossowska, J., Dubińska-Magiera, M., Choromańska, A., Wilk, K.A., 2016. Preparation and characterization of new zinc(II) phthalocyanine - Containing poly(l-lactide)-b-poly(ethylene glycol) copolymer micelles for photodynamic therapy. J Photochem Photobiol B. 160, 185-197. doi: 10.1016/j.jphotobiol.2016.04.018.

Lan, W.L., Liu, F.R., Ke, M.R., Lo, P.C., Fong, W.P., Ng, D.K.P., Huang J.D., 2016. The effects of formulation and serum albumin on the in vitro photodynamic activity of zinc(II) phthalocyanines substituted with sulfonated quinolineoxy groups. Dyes Pigm. 128, 215-225. doi: 10.1016/j.dyepig.2016.01.031.

Larroque, C., Pelegrin, A., Van Lier, J.E., 1996. Serum albumin as a vehicle for zinc phthalocyanine: photodynamic activities in solid tumour models. Br J Cancer. 74(12), 18861890.

Lee, J., Kim, J., Jeong, M., Lee, H., Goh, U., Kim, H., Kim, B., Park, J.H., 2015. Liposomebased engineering of cells to package hydrophobic compounds in membrane vesicles for tumor penetration. Nano Lett. 15(5), 2938-44. doi: 10.1021/n15047494.

Leznoff, C.C., Marcuccio, S.M., Greenberg S., Lever A.B.P., Tomer, K.B., 1985. Metallophthalocyanine Dimers Incorporating Five Atom Covalent Bridges. Can. J. Chem. 63, 623-632. doi: 10.1139/v85-102.

Leznoff, C.C., Lever, A.B.P., 1989. Phthalocyanines: Properties and Applications. VCH, Vol. 2 .

Li, H., Jensen, T.J., Fronczek, F.R., Vicente, M.G.H., 2008. Synthesis and properties of a series of cationic water-soluble phthalocyanine. J. Med. Chem. 51, 502-511. doi.org 10.1021/jm070781f. 
Li, L., Luo, Z., Chen, Z., Chen, J., Zhou, S., Xu, P., Hu, P., Wang, J., Chen, N., Huang, J., Huang, M., 2012. Enhanced photodynamic efficacy of zinc phthalocyanine by conjugating to heptalysine. Bioconjug Chem. 23(11), 2168-2172.

Li, X., Zheng, B.Y., Ke, M.R., Zhang, Y., Huang, J.D., Yoon, J., 2017. A tumor-pHresponsive supramolecular photosensitizer for activatable photodynamic therapy with minimal in vivo skin phototoxicity. Theranostics. 7(10), 2746-2756. doi: 10.7150/thno.18861. eCollection 2017.

Liang, R., Ma, L., Zhang, L., Li, C., Liu, W., Wei, M., Yan, D., Evans, D.G., Duan, X., 2014a. A monomeric photosensitizer for targeted cancer therapy. Chem Commun (Camb). 50(95), 14983-14986. doi: 10.1039/c4cc07628a.

Liang, R., Tian, R., Ma, L., Zhang, L., Hu, Y., Wang, J., Wei,M., Yan, D. Evans, D.G., Duan, X., 2014b. A supermolecular photosensitizer with excellent anticancer performance in photodynamic therapy. Adv. Funct. Mater. 24, 3144-3151.

Liang, R., You, S., Ma, L., Li, C., Tian, R., Wei, M., Yan, D., Yin, M., Yang, W., Evans, D.G., Duan, X., 2015. A supramolecular nanovehicle toward systematic, targeted cancer and tumor therapy. Chem Sci. 6(10):5511-5518. doi: 10.1039/c5sc00994d.

Liu, W., Chen, N., Jin, H., Huang, J., Wei, J., Bao, J., Li, C., Liu, Y., Li, X., Wang, A., 2007. Intravenous repeated-dose toxicity study of $\mathrm{ZnPcS} 2 \mathrm{P} 2$-based-photodynamic therapy in beagle dogs. Regul Toxicol Pharmacol. 47(3), 221-231.

Liu, X., Fan, Z., Zhang, L., Jin, Z., Yan, D., Zhang, Y., Li, X., Tu, L., Xue, B., Chang, Y., Zhang, H., Kong, X., 2017. Bcl-2 inhibitor uploaded upconversion nanophotosensitizers to overcome the photodynamic therapy resistance of cancer through adjuvant intervention strategy. Biomaterials 144, 73-83. doi: 10.1016/j.biomaterials.2017.08.010.

Lo, P.C., Zhao, B., Duan, W., Fong, W.P., Ko, W.H., Ng, D.K., 2007. Synthesis and in vitro photodynamic activity of mono-substituted amphiphilic zinc(II) phthalocyanines. Bioorg. Med. Chem. Lett. 17(4), 1073-1077.

Lopez, T., Ortiz, E., Alvarez, M., Navarrete, J., Odriozola, J.A., Martinez-Ortega, F., PáezMozo, E.A., Escobar, P., Espinoza, K.A., Rivero, I.A., 2010. Study of the stabilization of zinc phthalocyanine in sol-gel $\mathrm{TiO} 2$ for photodynamic therapy applications. Nanomedicine 6(6), 777-785.

López Zeballos, N.C., Marino, J., García Vior, M.C., Chiarante, N., Roguin, L.P., Awruch, J., Dicelio, L.E., 2013. Photophysics and photobiology of different liposomal formulations of 2,9(10),16(17),23(24)-tetrakis[(2dimethylamino)ethylsulfanyl] phthalocyaninatozinc(II). Dyes Pigments 96, 626-635. 
Lu, S., Wang, A., Ma, Y.J., Xuan, H.Y., Zhao, B., Li, X.D., Zhou, J.H., Zhou, L., Wei, S.H., 2016. Cyclodextrin type dependent host-guest interaction mode with phthalocyanine and their influence on photodynamic activity to cancer. Carbohydr Polym. 148, 236-242.

Lucroy M.D., 2006. Squamous cell carcinoma of dogs and cats: and ideal test system for head and neck PDT protocols. Proc. of SPIE 6078, 1-7. doi: 10.1117/12.643007.

Machado, A.H., Pacheco Soares, C., da Silva, N.S., Moraes, K.C., 2009. Cellular and molecular studies of the initial process of the photodynamic therapy in HEp-2 cells using LED light source and two different photosensitizers. Cell Biol Int. 33(7), 785-795. doi: 10.1016/j.cellbi.2009.04.011.

Madsen, S.J., Sun, C., Tromberg, B.J., Cristini, V., Magalhaes, N., Hirschberg, H., 2006. Multicell tumour spheroids in photodynamic therapy. Lasers Surg. Med. 38, 555-564.

Manoto, S.L., Sekhejane, P.R., Houreld, N.N., Abrahamse, H., 2012. Localization and phototoxic effect of zinc sulfophthalocyanine photosensitizer in human colon (DLD-1) and lung (A549) carcinoma cells (in vitro). Photodiagnosis Photodyn. Ther. 9(1), 52-59.

Manoto, S.L., Houreld, N.N., Abrahamse, H., 2013. Phototoxic effect of photodynamic therapy on lung cancer cells grown as a monolayer and three dimensional multicellular spheroids. Lasers Surg. Med. 45(3), 186-194.

Manoto, S.L., Houreld, N.N., Abrahamse, H., 2015. Resistance of lung cancer cells grown as multicellular tumour spheroids to zinc sulfophthalocyanine photosensitization. Int J Mol Sci. 16(5), 10185-10200.

Manoto, S.L., Oluwole, D.O., Malabi, R., Maphanga, C., Ombinda-Lemboumba, S., Nyokong, T., 2017a. Phototodynamic activity of zinc monocarboxyphenoxy phthalocyane (ZnMCPPc) conjugated to gold silver $(\mathrm{AuAg})$ nanoparticles in melanoma cancer cells. Optical Methods for Tumor Treatment and Detection: Mechanisms and Techniques in Photodynamic Therapy XXVI, ed David H. Kessel, Tayyaba Hasan, Proc. of SPIE Vol. 10047, 1004716. doi: 10.1117/12.2252838.

Manoto, S.L., Houreld, N., Hodgkinson, N., Abrahamse, H., 2017b. Modes of cell death induced by photodynamic therapy using zinc phthalocyanine in lung cancer cells grown as a monolayer and three-dimensional multicellular spheroids. Molecules 22(5), 791.

Margaron, P., Grégoire, M.J., Scasnárt, V., Ali, H., van Lier, J.E., 1996. Structurephotodynamic activity relationships of a series of 4-substituted zinc phthalocyanines. Photochem. Photobiol. 63, 217-223. 
Marino, J., Garcia Vior, M.C., Dicelio, L.E., Roguin, L.P., Awruch, J., 2010. Photodynamic effects of isosteric water-soluble phthalocyanines on human nasopharynx $\mathrm{KB}$ carcinoma cells. Eur. J. Med. Chem. 45, 4129-4139. doi: 10.1016/j.ejmech.2010.06.002.

Marino, J., García Vior, M.C., Furmento, V.A., Blank, V.C., Awruch, J., Roguin, L.P., 2013. Lysosomal and mitochondrial permeabilization mediates zinc(II) cationic phthalocyanine phototoxicity. Int J Biochem Cell Biol. 45(11):2553-2562. doi: 10.1016/j.biocel.2013.08.012.

Marrache, S., Choi, J.H., Tundup, S., Zaver, D., Harn, D.A., Dhar, S., 2013. Immune stimulating photoactive hybrid nanoparticles for metastatic breast cancer. Integr Biol (Camb) 5(1), 215-23. doi: 10.1039/c2ib20125a.

Medina, W.S., dos Santos, N.A., Curti, C., Tedesco, A.C., dos Santos, A.C., 2009. Effects of zinc phthalocyanine tetrasulfonate-based photodynamic therapy on rat brain isolated mitochondria. Chem Biol Interact. 179(2-3), 402-406.

Mfouo-Tynga, I.M., Houreld, N.N., Abrahamse, H., 2013. The primary subcellular localization of Zinc phthalocyanine and its cellular impact on viability, proliferation and structure of breast cancer cells (MCF-7). J. Photochem. Photobiol. B. 120, 171-176.

Mfouo-Tynga, I., Houreld, N.N., Abrahamse, H., 2014. Induced cell death pathway post photodynamic therapy using a metallophthalocyanine photosensitizer in breast cancer cells. Photomed Laser Surg. 32(4), 205-211. doi: 10.1089/pho.2013.3650.

Mfouo-Tynga, I., Houreld, N.N., Abrahamse, H., 2018a. Characterization of a multiple particle delivery complex and determination of cellular photodamage in skin fibroblast and breast cancer cell lines. J Biophotonics. 11(2). doi: 10.1002/jbio.201700077.

Mfouo-Tynga, I., Houreld, N.N., Abrahamse, H., 2018b. Evaluation of cell damage induced by irradiated Zinc-Phthalocyanine-gold dendrimeric nanoparticles in a breast cancer cell line. Biomed J. 41(4), 254-264. doi: 10.1016/j.bj.2018.05.002.

Milanesi, C., Zhou, C., Jori, G., 1990. Zn(II)-phthalocyanine as a photodynamic agent for tumors. II. Studies on the mechanism of photosensitised tumour necrosis, Br. J. Cancer 61, 846-850. doi: 10.1038/bjc.1990.189.

Milla, L.N., Yslas, E.I., Cabral, A., Durantini, E.N., Romanini, S., Rivarola, V., Bertuzzi, M., 2009. Pharmacokinetic, toxicological and phototherapeutic studies of phthalocyanine ZnPcCF3. Biomed Pharmacother. 63(3), 209-215. doi: 10.1016/j.biopha.2008.01.019.

Moserova, I., Kralova, J., 2012. Role of ER stress response in photodynamic therapy: ROS generated in different subcellular compartments trigger diverse cell death pathways. PLoS One 7 (3), e32972. doi: 10.1371/journal.pone.0032972. 
Mroz, P.; Szokalska, A.; Wu, M.X.; Hamblin, M.R., 2010. Photodynamic therapy of tumors can lead to development of systemic antigen-specific immune response. PLoS One 5, e15194.

Muli, D.K., Rajaputra, P., You, Y., McGrath, D.V., 2008. Asymmetric ZnPc-rhodamine B conjugates for mitochondrial targeted photodynamic therapy. Bioorg. Med. Chem. Lett. 24(18), 4496-4500.

Muli, D.K., Rajaputra, P., You, Y., McGrath, D.V., 2015. Asymmetric ZnPc-TEG photosensitizers: the effect of Pc substitution on phototoxicity. Tetrahedron Lett. 56, 62366239. doi: 10.1016/j.tetlet.2015.09.101.

Nag, O.K., Naciri, J., Erickson, J.S., Oh, E., Delehanty, J.B., 2018. Hybrid liquid crystal nanocarriers for enhanced zinc phthalocyanine-mediated photodynamic therapy. Bioconjug Chem. 29(8), 2701-2714.

Nyokong, T., Antunes, E., 2010 in: Kadish K., Smith K,. Guilard R. (Eds.) Handbook of Porphyrins Science, vol 7, World Scientific Publishing Co. Pte. Ltd.

Obata, T., Mori, S., Suzuki, Y., Kashiwagi, T., Tokunaga, E., Shibata, N., Tanaka, M., 2015. Photodynamic therapy using novel zinc phthalocyanine derivatives and a diode laser for superficial tumors in experimental animals. Journal of Cancer Therapy 6, 53-61.

Oleinick, N.L., Morris, R.L., Belichenko, I., 2002. The role of apoptosis in response to photodynamic therapy: what, where, why, and how. Photochemical and Photobiological Sciences 1, 1-21.

Oliveira, C.S., Turchiello, R., Kowaltowski, A.J., Indig, G.L., Baptista, M.S., 2011. Major determinants of photoinduced cell death: Subcellular localization versus photosensitization efficiency. Free Radical Biology and Medicine 51, 824-833.

Oluwole, D.O., Uddin, I., Prinsloo, E., Nyokong, T., 2016. The effects of silica based nanoparticles on the photophysicochemical properties, in vitro dark viability and photodynamic therapy study of zinc monocarboxyphenoxy phthalocyanine. J. Photochem. Photobiol. A: Chemistry 329, 221-231.

Oluwole, D.O., Manoto, S.L., Malabi, R., Maphanga, C., Ombinda-Lemboumba, S., Mthunzi-Kufa, P., Nyokong, T., 2017. Evaluation of the photophysicochemical properties and photodynamic therapy activity of nanoconjugates of zinc phthalocyanine linked to AuNPs-GSH and Au3Ag1NPs-GSH. Dyes and Pigments 150, 139-150.

Ongarora B.G., Fontenot K.R., Hu X., Sehgal I., Satyanarayana-Joisand S.D., Vicente M.G.H., 2012a. Phthalocyanine-peptide conjugates for epidermal growth factor receptor targeting. J. Med. Chem. 55, 3725-3738. http://dx.doi.org/ 10.1021/jm201544y. 
Ongarora, B.G., Hu, X., Verberne-Sutton, S.D., Garno, J.C., Vicente, M.G.H., 2012b. Syntheses and Photodynamic Activity of Pegylated Cationic Zn(II)-Phthalocyanines in HEp2 Cells. Theranostics 2(9), 850-870.

Paquette, B., Boyle, R.W., Ali, H., MacLennan, A.H., Truscott, T.G., van Lier, J.E., 1991. Sulfonated phthalimidomethyl aluminum phthalocyanine: the effect of hydrophobic substituents on the in vitro phototoxicity of phthalocyanines. Photochem. Photobiol. 53(3), 323-327.

Peng, X.H., Chen, S.F., Zheng ,B.Y., Zheng, B.D., Zheng, Q.F., Li, X.S., Ke, M.R., Huang, J.D., 2017. Comparison between amine-terminated phthalocyanines and their chlorambucil conjugates: Synthesis, spectroscopic properties, and in vitro anticancer activity. Tetrahedron 73(4), 378-384.

Pereira, P.M., Carvalho, J.J., Silva, S., Cavaleiro, J.A.S., Schneider, R.J., Fernandes, R., Tomé, J.P.C., 2014a. Porphyrin conjugated with serum albumins and monoclonal antibodies boosts efficiency in targeted destruction of human bladder cancer cells. Organic and Biomolecular Chemistry 12, 1804-1811.

Pereira, P.M., Silva, S., Cavaleiro, J.A., Ribeiro, C.A., Tomé, J.P., Fernandes, R., 2014b. Galactodendritic phthalocyanine targets carbohydrate-binding proteins enhancing photodynamic therapy. PLoS One. 9(4):e95529. doi: 10.1371/journal.pone.0095529. eCollection 2014.

Ping, J., Peng, H., Duan, W., You, F., Songa, M., Wang, Y., 2016. Synthesis and optimization of ZnPc-loaded biocompatible nanoparticles for efficient photodynamic therapy. Journal of Materials Chemistry B 4(25). 1-21. doi: 10.1039/c6tb00307a.

Plaetzer, K., Krammer, B., Berlanda, J., Berr, F., Kiesslich, T., 2009. Photophysics and photochemistry of photodynamic therapy: fundamental aspects. Lasers Med. Sci. 24(2), 259268

Portilho, F.A., Cavalcanti, C.E., Miranda-Vilela, A.L., Estevanato, L.L., Longo, J.P., Almeida Santos, M. de F., et al., 2013. Antitumor activity of photodynamic therapy performed with nanospheres containing zinc-phthalocyanine. J Nanobiotechnology. 11, 41. doi: 10.1186/1477-3155-11-41.

Primo FL1, Rodrigues MM, Simioni AR, Lacava ZG, Morais PC, Tedesco AC., 2008. Photosensitizer-loaded magnetic nanoemulsion for use in synergic photodynamic and magnetohyperthermia therapies of neoplastic cells. J Nanosci Nanotechnol. 8(11), 58735877. 
Pucelik, B., Gürol, I., Ahsen, V., Dumoulin, F., Dąbrowski, J.M., 2016. Fluorination of phthalocyanine substituents: Improved photoproperties and enhanced photodynamic efficacy after optimal micellar formulations. Eur J Med Chem. 124, 284-298. doi: 10.1016/j.ejmech.2016.08.035.

Raab, O., 1900. Uber die Wirkung fluoreszierender Stoffe auf Infusorien. Zeitung Biol. 39, 524-546.

Ramírez-García, G., Panikar, S.S., López-Luke, T., Piazza, V., Honorato-Colin, M.A., Camacho-Villegas, T., Hernández-Gutiérrez, R., De la Rosa, E., 2018. An immunoconjugated up-conversion nanocomplex for selective imaging and photodynamic therapy against HER2-positive breast cancer. Nanoscale. 10(21), 10154-10165. doi: $10.1039 / \mathrm{c} 8 \mathrm{nr} 01512 \mathrm{k}$.

Reddi, E., Zhou, C., Biolo, R., Menegaldo, E., Jori, G., 1990. Liposome- or LDLadministered $\mathrm{Zn}$ (II)-phthalocyanine as a photodynamic agent for tumours. I. Pharmacokinetic properties and phototherapeutic efficiency. Br. J. Cancer 61, 407-411.

Reiners, J.J.Jr., Caruso, J.A., Mathieu, P., Chelladurai, B., Yin, X.M., Kessel, D., 2002. Release of cytochrome $\mathrm{c}$ and activation of pro-caspase-9 following lysosomal photodamage involves Bid cleavage. Cell Death Differ. 9(9), 934-944.

Rello-Varona, S., Stockert. J.C., Cañete, M., Acedo, P., Villanueva, A., 2008. Mitotic catastrophe induced in HeLa cells by photodynamic treatment with $\mathrm{Zn}$ (II)-phthalocyanine. Int J Oncol. 32(6), 1189-1196.

Ricci-Junior, E., de Oliveira de Siqueira, L.B., Rodrigues, R.A.S., Sancenón, F., MartínezMáñez, R., de Moraes, J.A., Santos-Oliveira, R., 2018. Nanocarriers as phototherapeutic drug delivery system: Appraisal of three different nanosystems in an in vivo and in vitro exploratory study. Photodiagnosis Photodyn Ther. 21, 43-49. doi: 10.1016/j.pdpdt.2017.11.003.

Rück, A., Beck, G., Bachor, R., Akgün, N., Gschwend, M.H., Steiner, R., 1996. Dynamic fluorescence changes during photodynamic therapy in vivo and in vitro of hydrophilic A1(III) phthalocyanine tetrasulphonate and lipophilic $\mathrm{Zn}$ (II) phthalocyanine administered in liposomes. J Photochem Photobiol B. 36(2), 127-133.

Rumie Vittar, N.B., Awruch, J., Azizuddin, K., Rivarola, V. 2010. Caspase-independent apoptosis, in human MCF-7c3 breast cancer cells, following photodynamic therapy, with a novel water-soluble phthalocyanine. Int J Biochem Cell Biol. 42(7), 1123-1131. doi: 10.1016/j.biocel.2010.03.019. 
Rumie Vittar, N.B., Prucca, C.G., Strassert, C., Awruch, J., Rivarola, V.A., 2008. Cellular inactivation and antitumor efficacy of a new zinc phthalocyanine with potential use in photodynamic therapy. Int $\mathbf{J}$ Biochem Cell Biol. 40(10), 2192-2205. doi: 10.1016/j.biocel.2008.02.024.

Sekhejane, P.R., Houreld, N.N., Abrahamse, H., 2014. Multiorganelle localization of metallated phthalocyanine photosensitizer in colorectal cancer cells (DLD-1 and CaCo-2) enhances efficacy of photodynamic therapy. International Journal of Photoenergy Article ID 383027.

Shao, J., Xue, J., Dai, Y., Liu, H., Chen, N., Jia, L., Huang, J., 2012. Inhibition of human hepatocellular carcinoma HepG2 by phthalocyanine photosensitiser PHOTOCYANINE: ROS production, apoptosis, cell cycle arrest. Eur J Cancer. 2012 48(13), 2086-2096. doi: 10.1016/j.ejca.2011.10.013.

Shao, J., Dai, Y., Zhao, W., Xie, J., Xue, J., Ye, J., Jia, L., 2013. Intracellular distribution and mechanisms of actions of photosensitizer Zinc(II)-phthalocyanine solubilized in Cremophor EL against human hepatocellular carcinoma HepG2 cells. Cancer Lett. 330(1), 49-56.

Sharman, W.M., Allen, C.M., van Lier, J.E., 1999. Photodynamic therapeutics: basic principles and clinical applications. Drug Discovery Today 11, 507-517.

Shoin, K., Yamashita, J., Enkaku, F., Sasaki, T., Tanaka, M. and Endo, Y., 1991. Chick embryo assay as chemosensitivity test for malignant glioma. Cancer Science 82, 1165-1170. Shopova, M., Mantareva, V., Krastev, K., Hadjiolov, D., Milev, A., Spirov, K., Jori, G., Ricchelli, F., 1992. Comparative pharmacokinetic and photodynamic studies with zinc(I1) phthalocyanine in hamsters bearing an induced or transplanted rhabdomyosarcoma. J. Photochem. Photobiol. B: Biol. 16, 83-89.

Shopova, M., Wohrle, D., Stoichkova, N., Milev, A., Mantareva, V., Muller, S., Kassabov, K., Georgiev, K., 1994. Hydrophobic Zn(II)-naphthalocyanines as photodynamic therapy agents for Lewis lung carcinoma. J Photochem Photobiol B. 23(1), 35-42.

Sibrian-Vazquez, M., Ortiz, J., Nesterova, I.V., Fernandez-Lazaro, F., Sastre-Santos, A., Soper, S.A., Vicente, M.G., 2007. Synthesis and properties of cell-targeted Zn(II)phthalocyanine-peptide conjugates. Bioconjug. Chem. 18(2), 410-420.

Soriano J., Villanueva A., Stockert J.C., Cañete M., 2013. Vehiculization determines the endocytic internalization mechanism of $\mathrm{Zn}(\mathrm{II})$-phthalocyanine. Histochem. Cell Biol. 139(1), 149-160. 
Soriano, J., Villanueva, A., Stockert, J.A., Cañete, M., 2014. Regulated necrosis in HeLa cells Induced by ZnPc photodynamic treatment: a new nuclear morphology. Int. J. Mol. Sci. 15(12), 22772-22785.

Stockert J.C., Juarranz A, Villanueva A, Nonell S, Horobin R.W., Soltermann A.T., et al., 2004. Photodynamic therapy: selective uptake of photosensitizing drugs into tumor cells. Current Topics in Pharmacology 8, 185-217. doi: 10.1111/php.12602.

Sun, Y., Hu, H., Zhao, N., Xia, T., Yu, B., Shen, C., Xu, F.J., 2017. Multifunctional polycationic photosensitizer conjugates with rich hydroxyl groups for versatile water-soluble photodynamic therapy nanoplatforms. Biomaterials. 117, 77-91. doi: 10.1016/j.biomaterials.2016.11.055.

Sutherland, R.M., Inch, W.R., McCredie, J.A., Kruuv, J., 1970. A multicomponent radiation survival curve using an in vivo tumour model. Int. J. Radic. Biol. 18, 491-495.

Tian, G., Ren, W., Yan, L., Jian, S., Gu, Z., Zhou, L., Jin, S., Yin, W., Li, S., Zhao, Y., 2013. Red-emitting upconverting nanoparticles for photodynamic therapy in cancer cells under near-infrared excitation. Small. 9(11), 1929-1938. doi: 10.1002/smll.201201437.

Toyota, H., Yanase, N., Yoshimoto, T., Moriyama, M., Sudo, T., Mizuguchi, J., 2003. Calpain-induced Bax-cleavage product is a more potent inducer of apoptotic cell death than wild-type Bax. Cancer Lett. 189, 221-230.

Tu, J., Wang, T., Shi, W., Wu, G., Tian, X., Wang, Y., Ge, D., Ren, L., 2012. Multifunctional ZnPc-loaded mesoporous silica nanoparticles for enhancement of photodynamic therapy efficacy by endolysosomal escape. Biomaterials. 33(31), 7903-7914. doi: 10.1016/j.biomaterials.2012.07.025.

Uchida, H., Sasaki, T., Tanaka, M., Endo, Y., Nitta, K., Nishikawa, K., Chuman, H., Fukuma, H. and Matsumoto, K., 1987. Response to antitumor agents of murine transplantable tumors implanted onto chorioallantoic membrane of chick embryo. Japanese Journal of Cancer Research 78, 729-736.

Valli, F., García Vior, M.C., Roguin, L.P., Marino, J., 2019. Oxidative stress generated by irradiation of a zinc(II) phthalocyanine induces a dual apoptotic and necrotic response in melanoma cells. Apoptosis 24(1-2), 119-134.

van Leengoed, H.L., Cuomo, V., Versteeg, A.A., van der Veen, N., Jori, G., Star, W.M., 1994. In vivo fluorescence and photodynamic activity of zinc phthalocyanine administered in liposomes. Br J Cancer. 69(5), 840-845. 
van Straten, D., Mashayekhi, V., de Bruijn, H.S., Oliveira, S., Robinson, D.J., 2017. Oncologic photodynamic therapy: basic principles, current clinical status and future directions. Cancers (Basel). 9(2), 1-54. pii: E19. doi: 10.3390/cancers9020019.

Venkatramaiah, N., Pereira, P.M.R., Almeida, Paz, F.A., Ribeiro, C.A.F., Fernandes, R., Tomé, J.P.C., 2015. Dual functionality of phosphonic acid appended phthalocyanines: inhibitors of urokinase plasminogen activator and anticancer photodynamic agents. Chem Commun. (Camb) 51, 15550-155543. doi: 10.1039/c5cc06561e.

Von Tappeiner, H., 1900. Uber die Wirkung fluoreszierender Stoffe auf Infusorien nach Versuchen von O. Raab. Muench. Med. Wochenschr. 47, 5.

Wang, A., Zhou, L., Fang, K., Zhou, L., Lin, Y, Zhou, Y., Wei, S., 2012. Synthesis of novel octa-cationic and non-ionic 1,2-ethanediamine substituted zinc(II) phthalocyanines and their in vitro anti-cancer activity comparison. Eur. J. Med. Chem. 58, 12-21. doi: 10.1016/j.ejmech.2012.09.038.

Wang A., Li Y. Zhou L., Yuang L. Lu S.,Lin Y., Zhou J.,Wei S., 2014. Charge dependent photodynamic activity of alanine based zinc phthalocyanine. J. Photochem. Photobiol B: Biol., 141, 10-19. doi:10.1016/j.jphotobiol.2014.09.002.

Wang, A., Zhou, R., Zhou, L., Sun, K., Jiang, J., Wei, S., 2017. Positively charged phthalocyanine-arginine conjugates as efficient photosensitizer for photodynamic therapy. Bioorg Med Chem. 25(5), 1643-1651.

Wang, H.J., Wang, S., Liu, Z., Dong, C., Yang, J., Gong, X., Chang, J., 2014a. Upconverting crystal/dextran-g-DOPE with high fluorescence stability for simultaneous photodynamic therapy and cell imaging. Nanotechnology. 25(15), 155103.

Wang, H.J., Shrestha, R., Zhang, Y., 2014b. Encapsulation of photosensitizers and upconversion nanocrystals in lipid micelles for photodynamic therapy. Part. Part. Syst. Charact. 31, 228-235.

Wang, M., Chen, Z., Zheng, W., Zhu, H., Lu, S., Ma, E., Tu, D., Zhou, S., Huang, M., Chen, X., 2014. Lanthanide-doped upconversion nanoparticles electrostatically coupled with photosensitizers for near-infrared-triggered photodynamic therapy. Nanoscale 6(14), 82748282. doi: 10.1039/c4nr01826e.

Wang, Y., Xia, C., Chen, W., Chen, Y., Wang, Y., Li, T., 2014. Autoregulatory feedback mechanism of p38MAPK/caspase-8 in photodynamic therapy-hydrophilic/lipophilic tetra- $\alpha$ (4-carboxyphenoxy) phthalocyanine zinc-induced apoptosis of human hepatocellular 
carcinoma Bel-7402 cells. International Journal of Photoenergy 2014(8), 1-9. doi: $\underline{10.1155 / 2014 / 163813 .}$

Wang, Y., Xia, C., Lun, Z., Lv, Y., Chen, W., Li, T., 2018a. Crosstalk between p38 MAPK and caspase-9 regulates mitochondria-mediated apoptosis induced by tetra- $\alpha-(4-$ carboxyphenoxy) phthalocyanine zinc photodynamic therapy in LoVo cells. Oncol Rep. 39(1), 61-70. doi: 10.3892/or.2017.6071.

Wang, Y., Zheng, K., Xuan, G., Huang, M., Xue, J., 2018b. Novel pH-sensitive zinc phthalocyanine assembled with albumin for tumor targeting and treatment. Int $\mathbf{J}$ Nanomedicine. 13, 7681-7695. doi: 10.2147/IJN.S181199. eCollection 2018.

Winsborrow, B.G., Grondey, H., Savoie, H., Fyfe, C.A., Dolphin, D., 1997. Magnetic resonance imaging evaluation of photodynamic therapy-induced hemorrhagic necrosis in the murine M1 tumor model. Photochem Photobiol. 66(6), 847-852.

Weijer, R., Broekgaarden, M., Krekorian, M., Alles, L.K., van Wijk, A.C., Mackaaij, C., Verheij, J., van der Wal, A.C., van Gulik, T.M., Storm, G., Heger, M., 2016. Inhibition of hypoxia inducible factor 1 and topoisomerase with acriflavine sensitizes perihilar cholangiocarcinomas to photodynamic therapy. Oncotarget. 7(3), 3341-56. doi: 10.18632/oncotarget.6490.

Wood, S.R., Holroyd, J.A., Brown, S.B., 1997. The subcellular localization of Zn(II) phthalocyanines and their redistribution on exposure to light. Photochem. Photobiol. 65(3), 397-402. doi: 10.1111/j.1751-1097.1997.tb08577.x

Xia, C., Wang, Y., Chen, W., Yu, W., Wang, B., Li, T., 2011. New hydrophilic/lipophilic tetra- $\alpha$-(4-carboxyphenoxy) phthalocyanine zinc-mediated photodynamic therapy inhibits the proliferation of human hepatocellular carcinoma Bel-7402 cells by triggering apoptosis and arresting cell cycle. Molecules. 16(2), 1389-1401. doi: 10.3390/molecules 16021389.

Xu, D., Chen, X., Chen, K., Peng, Y., Li, Y., Ke, Y., Gan, D., 2014. Tetra-sulfonate phthalocyanine zinc-bovine serum albumin conjugate-mediated photodynamic therapy of human glioma. J Biomater Appl. 29(3), 378-385. doi: 10.1177/0885328214529466.

Xue, J., Li, C., Liu, H., Wei, J., Chen, N., Huang, J., 2011. Optimal light dose and drug dosage in the photodynamic treatment using PHOTOCYANINE. Photodiagnosis Photodyn Ther. 8(3), 267-274. doi: 10.1016/j.pdpdt.2010.10.003.

Yan, S., Chen, J., Cai, L., Xu, P., Zhang, Y., Li, S., Hu, P., Chen, X., Huang, M., Chen, Z., 2018a. Phthalocyanine-based photosensitizer with tumor-pHresponsive properties for cancer theranostics. J. Mater. Chem. B 6(38) doi: 0.1039/C8TB01884G. 
Yan, S., Song, X., Liu, Y., Dai, T., Huang, M., Chen, X., Chen, Z., 2018b. An efficient synergistic cancer therapy by integrating cell cycle inhibitor and photosensitizer into polydopamine nanoparticles. J. Mater. Chem. B. 6, 2620-2629.

Yang, Y.M., Ren, L., Wang, H.J., 2017. Strategies in the design of gold nanoparticles for intracellular targeting: opportunities and challenges. Therapeutic Delivery 8, 879-898.

Yslas, E.I., Durantini, E.N., Rivarola, V.A., 2007. Zinc-(II) 2,9,16,23-tetrakis (methoxy) phthalocyanine: potential photosensitizer for use in photodynamic therapy in vitro. Bioorg. Med. Chem. 15(13), 4651-4660.

Yslas, E.I., Prucca, C., Romanini, S., Durantini, E.N., Bertuzzi, M., Rivarola, V., 2009. Biodistribution and phototherapeutic properties of Zinc (II) 2,9,16,23-tetrakis (methoxy) phthalocyanine in vivo. Photodiagnosis Photodyn Ther. 6(1), 62-70. doi: 10.1016/j.pdpdt.2009.03.001.

Yslas, E.I., Milla, L.N., Romanini, S., Durantini, E.N., Bertuzzi, M., Rivarola, V.A., 2010. Comparative photodynamic therapy study using two phthalocyanine derivatives. Exp Ther Med. 1(4), 713-718.

Yu, L., Wang, Q., Yeung, K.W., Fong, W.P., Lo, P.C., 2018. A biotinylated and endoplasmic reticulum-targeted glutathione-responsive zinc(II) phthalocyanine for targeted photodynamic therapy. Chem Asian J. 13(22), 3509-3517. doi: 10.1002/asia.201800852.

Yu, W., Ye, M., Zhu, J., Wang, Y., Liang, C., Tang, J., Tao, H., Shen, Y., 2018. Zinc phthalocyanine encapsulated in polymer micelles as a potent photosensitizer for the photodynamic therapy of osteosarcoma. Nanomedicine 14(4), 1099-1110.

Yu, W., Wang, Y., Zhu, J., Jin, L., Liu, B., Xia, K., Wang, J., Gao, J., Liang, C., Tao, H., 2019. Autophagy inhibitor enhance ZnPc/BSA nanoparticle induced photodynamic therapy by suppressing PD-L1 expression in osteosarcoma immunotherapy. Biomaterials 192, 128139. doi: 10.1016/j.biomaterials.2018.11.019.

Yurt, F., Ince, M., Colak, S.G., Ocakoglu, K., Er, O., Soylu, H.M., Gunduz, C., Avci, C.B., Kurt, C.C., 2017. Investigation of in vitro PDT activities of zinc phthalocyanine immobilised TiO2 nanoparticles. Int J Pharm. 524(1-2), 467-474. doi: 10.1016/j.ijpharm.2017.03.050.

Zamani, A.R.N., Mashayekhi, M.R., Jadid, M.F.S., Faridvand, Y., Tajalli, H., Rahbarghazi, R., 2018. Photo-modulation of zinc phthalocyanine-treated breast cancer cell line ZR-75-1 inhibited the normal tumor activity in vitro. Lasers Med Sci. 33(9), 1969-1978. doi: 10.1007/s10103-018-2563-0.

Zhang, M., Murakami, T., Ajima, K., Tsuchida, K., Sandanayaka, A.S., Ito, O., Iijima, S., Yudasaka, M., 2008. Fabrication of ZnPc/protein nanohorns for double photodynamic and 
hyperthermic cancer phototherapy. Proc Natl Acad Sci U S A. 105(39), 14773-14778. doi: 10.1073/pnas.0801349105.

Zhang, Z., Jin, H., Bao, J., Fang, F., Wei, J., Wang, A., 2006. Intravenous repeated-dose toxicity study of $\mathrm{ZnPcS} 2 \mathrm{P} 2$-based-photodynamic therapy in Wistar rats. Photochem Photobiol Sci. 5(11), 1006-1017.

Zhou, L., Chen, E., Jin, W., Wang, Y., Zhou, J., Wei, S., 2016. Monomer zinc phthalocyanine/upconversion nanoparticle coated with hyaluronic acid crosslinked gel as NIR light-activated drug for in vitro photodynamic therapy. Dalton Trans. 45, 15170-15179. doi :10.1039/C6DT01929C.

\section{Legends to Figures}

Figure 1. Chemical structure of $\mathrm{ZnPc}(\mathrm{A}), \alpha$-tetrasubstituted $\mathrm{ZnPc}(\mathrm{B})$ and $\beta$ tetrasubstituted $\mathrm{ZnPc}(\mathrm{C})$

Figure 2. Main intracellular sites of ZnPcs localization. After irradiation, ZnPcs promote the generation of ROS that triggers different phototoxic cellular responses. 
Figure 3. Mitochondria membrane permeabilization (MMP) induced by deregulation in the expression levels of Bcl-2 family proteins leads to activation of either caspasedependent and independent apoptosis.

Figure 4. Contribution of GA photodamage and lysosomal membrane permeabilization (LMP) to the activation of the mitochondrial-dependent apoptosis.

Figure 5. Involvement of ER stress induced by photoactivated ZnPcs in the mitochondrial apoptotic pathway. 

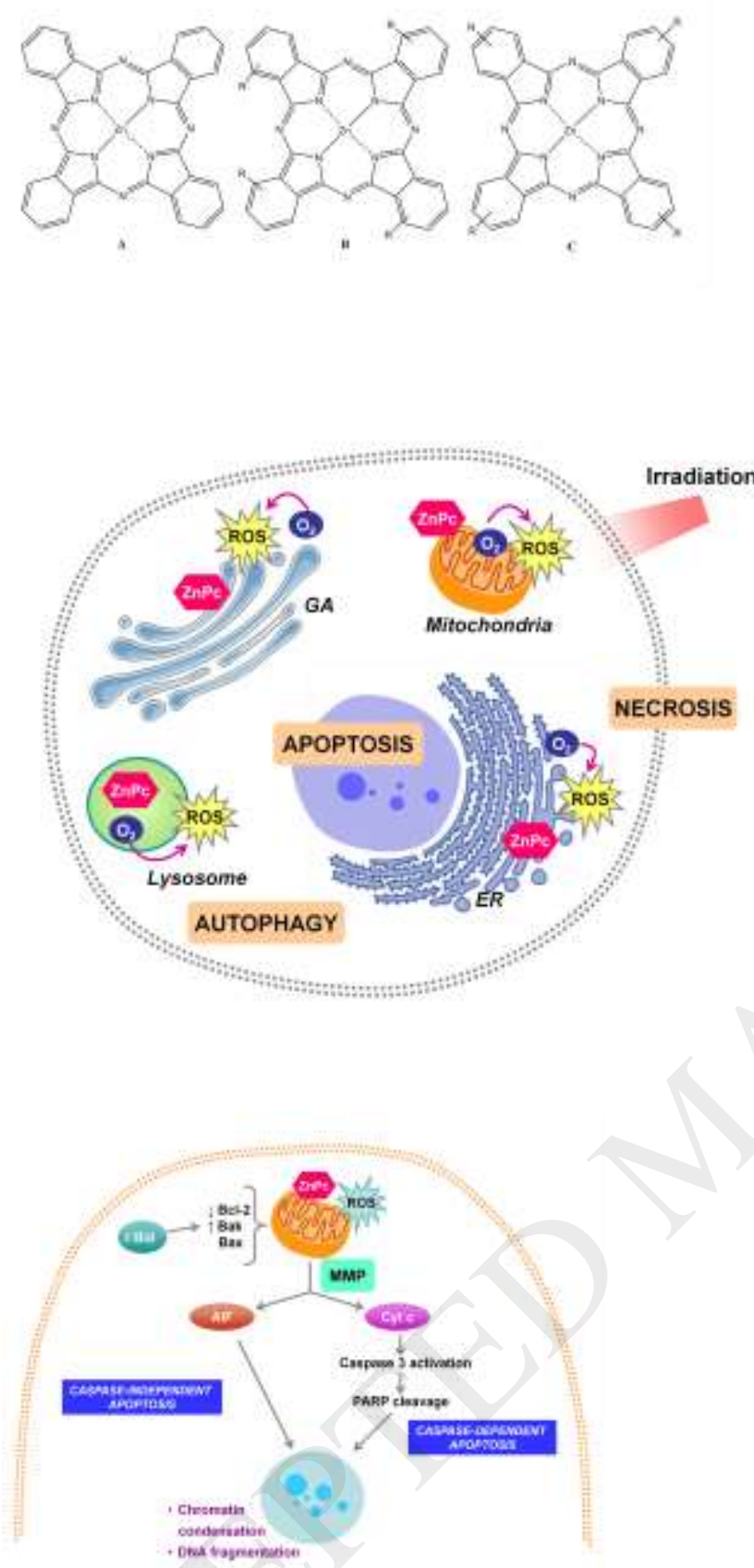

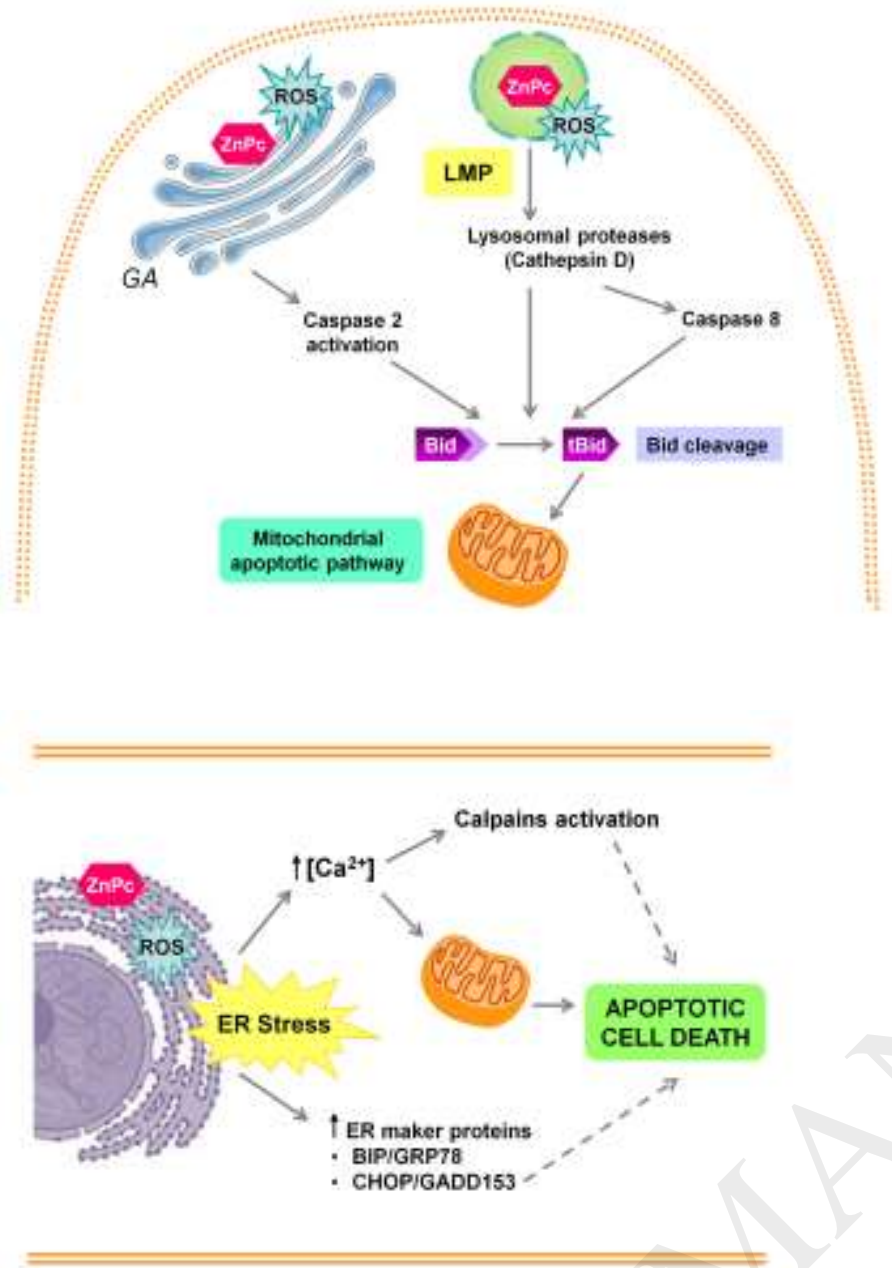